\title{
Neuronal patteming by BMPs: a requirement for GDF7 in the generation of a discrete class of commissural interneurons in the mouse spinal cord
}

\author{
Kevin J. Lee, Monica Mendelsohn, and Thomas M. Jessel $I^{1}$ \\ Howard Hughes Medical Institute (HHMI), Department of Biochemistry and Molecular Biophysics, Center for N eurobiology \\ and Behavior, Columbia University, N ew York, N ew York 10032 USA
}

Inductive factors are known to direct the regional differentiation of the vertebrate central nervous system (CNS) but their role in the specification of individual neuronal cell types is less clear. We have examined the function of GDF7, a BMP family member expressed selectively by roof plate cells, in the generation of neuronal cell types in the dorsal spinal cord. We find that GDF7 can promote the differentiation in vitro of two dorsal sensory intemeuron classes, D1A and D1B neurons. In G df7-null mutant embryos, the generation of D1A neurons is eliminated but D1B neurons and other identified dorsal intemeurons are unaffected. These findings show that GDF7 is an inductive signal from the roof plate required for the specification of neuronal identity in the dorsal spinal cord and that GDF7 and other BMP family members expressed by the roof plate have non-redundant functions in vivo. More generally, these results suggest that BMP signaling may have a prominent role in the assignment of neuronal identity within the mammalian CNS.

[Key Words: BMPs; neural patterning; spinal cord; commissural neurons]

Received July 22, 1998; accepted in revised form September 1, 1998.

The patterning of the vertebrate central nervous system (CNS) depends on the subdivision of the neural epithelium into distinct regional domains and the generation of a diverse array of neuronal cell types within each domain. The early regionalization of the neural epithelium appears to be regulated by inductive factors secreted by signaling centers in and adjacent to the neural tube (Lumsden and Krumlauf 1996; T anabe and Jessell 1996). Genetic studies and in vitro assays have provided evidence that signal ing factors of the Wnt, FGF, and Hedgehog families have prominent roles in the specification of these regional domains (McMahon and Bradley 1990; Thomas and Capecchi 1990; Chiang et al. 1996; Crossley et al. 1996; Ikeya et al. 1997; Lee et al . 1997; M eyers et al. 1998; Ye et al. 1998).

The factors responsible for the specification of individual neuronal subtypes within local regions of the developing CNS, however, remain less well defined. Sonic hedgehog (Shh) has been implicated in neuronal cell-type specification on the basis of in vitro studies in which the generation of distinct classes of ventral neuronal cell

${ }^{1}$ Corresponding author.

E-MAIL tmj1@columbiaedu; FAX (212) 568-8473. types is elicited by exposure of neural progenitor cells to different Shh concentrations (Roelink et al. 1995; M arti et al. 1995; Ericson et al. 1996, 1997). N evertheless, the elimination of Shh function in mice results in the loss of the entire ventral half of the embryonic CNS (Chiang et al. 1996), precluding a genetic assessment of the requirement for Shh signaling in the generation of individual neuronal cell types.

The T GF $\beta$ superfamily (Kingsl ey 1994) constitutes the largest known class of inductive signals and their capacity for heterodi mer formation extends further the potential diversity of TGF $\beta$-rel ated signals. Evidence for a role of TGF $\beta$-related proteins in the control of neuronal differentiation in the CN S has emerged in part from studies of cell patterning in the dorsal spinal cord (Basler et al. 1993; Liem et al. 1995, 1997). M embers of the BMP subclass of TGF $\beta$-related proteins are expressed by epidermal ectoderm cells that flank the neural plate (Liem et al. 1995; Lyons et al. 1995; Arkell and Beddington 1997; Dudl ey and Robertson 1997), and the induction of neural crest and roof plate differentiation by the epidermal ectoderm (Moury and Jacobson 1989; Dickinson et al. 1995; Liem et al. 1995) appears to be mediated by BM Ps (Liem et al. 1995, 1997). Roof plate cells at the dorsal midline of the neural tube subsequently express several 
BM Ps (Jones et al . 1991; Liem et al. 1995, 1997; Lyons et al. 1995; Arkell and Beddington 1997; Dudley and Robertson 1997) and in vitro assays have shown that BM Ps expressed by roof plate cells can promote the differentiati on of dorsal spinal cord interneurons (Liem et al . 1997). These findings have led to the idea that neuronal patterning in the dorsal spinal cord depends on a cascade of TGF $\beta$-related inductive signal ing that is initiated by the epidermal ectoderm and propagated by the roof plate.

Gene targeting studies in mice have demonstrated a number of essential functions for BMPs in mammalian development, notably in the differentiation of mesodermal tissues (King et al . 1994; Storm et al . 1994; Dudley et al. 1995; Luo et al. 1995; Winnier et al. 1995; Zhang and Bradley 1996). These studies, however, have not been informative in defining the contribution of BM Ps to neural tube patterning. Two major issues concerning the role of BMPS as dorsalizing signals in the CNS remain unresolved. Are the BMPs expressed by the roof plate required in vivo for the generation of dorsal neuronal cell types? And, if so, do roof plate-derived BM Ps have distinct or overlapping functions in the generation of dorsal neuronal cell types?

We have taken a genetic approach to define the requirement for individual BMPs in the control of neuronal identity in the dorsal spinal cord. This study focuses on GDF7, a BMP family member that we have found to be expressed sel ectively by roof plate cells in the embryonic CNS. GDF7 can mimic the ability of the roof plate to induce the differentiation in vitro of two classes of dorsal commissural interneurons, D1A and D1B neurons. To define the requirement for GDF7 signaling we generated a targeted mutation in the mouse Gdf7 gene. Gdf7 mutant embryos lack D1A neurons, but D1B neurons and other types of dorsal interneurons differentiate normally. Our results establish that GDF7 activity is required for the specification of neuronal identity in the spinal cord. They al so show that roof plate signaling has an essential role in dorsal neural patterning, distinct from that provided by epidermal ectoderm signals.

\section{Results}

Selective expression of G df7 by roof plate cells

To identify inductive factors that control the differentiation of dorsal interneurons in the mouse spinal cord, we analyzed the neural expression of BMP family members between E8.5 and E12.5, the period of generation of most dorsal interneurons (N ornes and Das 1974; Altman and Bayer 1984). Of nine BM P genes analyzed, only one, Gdf7 (Storm et al. 1994), was found to be expressed selectively by roof plate cells at the dorsal midline of the neural tube. Gdf7 expression in roof plate cells was first evident at E9 at hindbrain and rostral spinal cord levels (Fig. 1A) and was subsequently detected at all axial levels (Fig. 1B; data not shown) from the diencephal on to the sacral spinal cord. Gdf7 expression persisted throughout the neu-
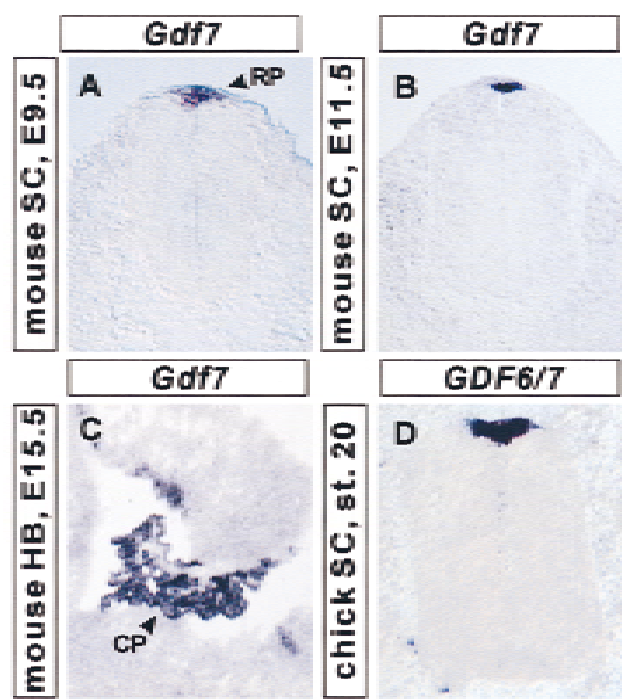

E

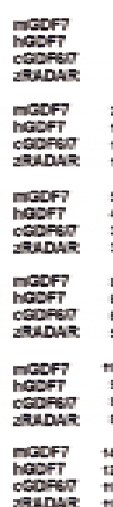

RRRRRTALRGTRERGESGGGGGGGGGG

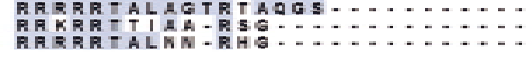
GGGGGGGGGAGRGRGRRGRSRCSRKSLH Y Y YDFKELGWDOWIIAPLOYEAYHCEGVCD

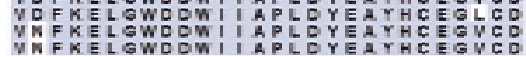
NWFKELGWDOWIIAPLOYEAYHCEGVCO FPLRSHERTMHAIIOTLLNS YAPOAAP

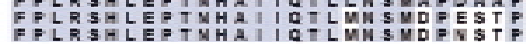

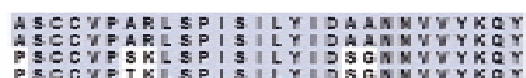
PSCCVPTKLSP

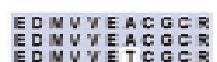

$\mathbf{F}$

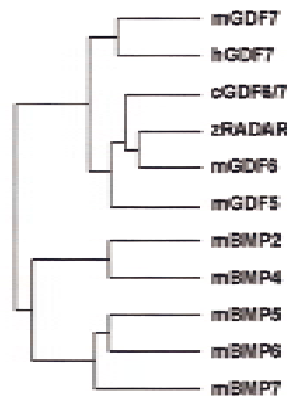

Figure 1. Expression of Gdf7 in the embryonic CNS. (A-C) Distribution of Gdf7 in the embryonic mouse CN S; (D) distribution of the related chick GDF6/7 gene in the devel oping chick spinal cord (SC). (A,B) Transverse sections through the mouse caudal neural tube showing Gdf7 expression in the roof plate (RP) at E9.5 (A) and at E11.5 (B). (C) Parasagittal section through the E15.5 mouse hindbrain (HB) showing Gdf7 expression in the choroid pl exus (CP) of the fourth ventricle. (D) Transverse section through stage 20 chick spinal cord showing sel ective expression of GDF6/7 in the roof plate. Although chick GDF6/7 is slightly more similar in sequence to mouse Gdf6 than mouse Gdf7 (see F), its expression pattern resembles that of Gdf7. (E) Sequence alignment of the predicted amino acid sequences of the mature carboxy-terminal domains of mouse (m) GDF7 (Storm et al. 1994), human (h) GDF7, chick (c) GDF6/7 and zebrafish (z) RADAR (Rissi et al. 1995). (F) Sequence relationship between mouse GDF7, human GDF7, chick GDF6/7, zebrafish RADAR, and other mouse BMP and GDF family members (Hogan 1996). Sequence similarity was determined by comparison of predicted amino acid sequences following the first cysteine residue of the mature carboxy-terminal domains. This dendrogram was generated by use of the Genetics Computer Group program PileUp. 
ral axis until E15.5, the latest stage examined (data not shown). The rel ated genes Gdf5 and Gdf6 (Storm et al . 1994) are not expressed in the embryonic spinal cord (data not shown).

Two other BMP genes, Bmp6 and Bmp7, are also expressed in roof plate cells (Fig. 4C,D, below; Jones et al. 1991; Lyons et al. 1995; Arkell and Beddington 1997; Dudley and Robertson 1997). Within the roof plate, the expression of Gdf7, Bmp6, and Bmp7 overlapped temporally and spatially, but Bmp6 and Bmp7 were both expressed more widely than Gdf7 in other regions of the CNS (data not shown). In addition, expression of Bmp7 was detected in epidermal ectoderm cells flanking the neural folds (data not shown; Dudley et al. 1995; Lyons et al. 1995; Arkell and Beddington 1997). Beginning at E13, expression of Gdf7, as well as Bmp6 and Bmp7 (Furuta et al. 1997), was detected in choroid plexus cells. Gdf7 was expressed solely in the choroid plexus of the fourth ventricle (Fig. 1C), whereas expression of Bmp6 and Bmp7 was also detected in lateral ventricle choroid plexus (data not shown; Furuta et al. 1997).

The patterns of neural expression of many members of the BM P family vary among different vertebrate species (Jones et al. 1991; Basler et al. 1993; Dudley and Robertson 1997; Liem et al. 1997). To determine whether the pattern of Gdf7 expression is conserved, we isolated a chick gene that encodes a BMP family member closely related to mouse GDF6 and GDF7 (Fig. 1E,F). This gene is also expressed selectively by roof plate cells (Fig. 1D). A closely related zebrafish gene, Radar, is expressed in the dorsal midline of the hindbrain and spinal cord (Rissi et al. 1995). Thus, the roof-plate-specific expression of a member of the Gdf7/Gdf6/Radar subfamily of Bmp genes appears conserved in vertebrate evolution.

Expression of mATH1 and LH2 transcription factors defines two classes of dorsal commissural interneurons

The time of onset and selectivity of expression of Gdf7 by roof plate cells suggested a role for this gene in the differentiation of interneurons generated close to the dorsal midline of the spinal cord. To begin to address this issue, we used the expression of transcription factors to define successive steps in the differentiation of distinct classes of dorsal interneurons in the spinal cord of mouse and chick embryos. The basic helix-loop-helix (bHLH) gene $\mathrm{mATH} 1$, and its chick homolog CATH1, are expressed by neural progenitor cells that are located adjacent to the roof plate of the spinal cord (Fig. 2A,E,I,M-P; Akazawa et al. 1995; Ben-A rie et al. 1996). Double labeling showed that laterally positioned $\mathrm{mATH} 1^{+} / \mathrm{CATH}^{+}$ progenitors express the LIM homeodomain proteins LH2A (Lhx2a) and LH2B (Lhx2b) (Fig. 2M-P; data not shown), markers of the D 1 class of commissural neurons (Liem et al. 1997). During the early stages of neurogenesis in the dorsal spinal cord, neuronal precursors migrate in a strict mediolateral plate (Leber and Sanes 1995). Thus, these data support the idea that $\mathrm{mATH}^{+} /$ $\mathrm{CATH} 1^{+}$progenitors give rise to D1 commissural neu- rons. The analysis of $\mathrm{mATH} 1 /$ lacZ transgenic mice has provided independent evidence for the generation of D1 commissural neurons from $\mathrm{mATH} 1^{+}$dorsal progenitors (Helms and Johnson 1998).

In the E10.5 mouse spinal cord, the domain of LH2A and LH2B expressi on overlapped compl etely, and expression of both genes was detected in all cells in this region (Fig. 2B,C; data not shown). Thus individual dorsal neurons appear initially to express both LH2A and LH2B. Between E10.5 and E12, a population of neurons that expresses LH2B but not LH2A, defined as D1B neurons, appears more ventrally and settles in the deep dorsal horn (Fig. 2F-H). Cell lineage tracing studies have reveal ed that neurons that are generated at dorsal positions in the spinal cord later migrate circumferentially, in a dorsal-to-ventral direction (Leber and Sanes 1995). The time of appearance and position of D1B neurons, together with the ventral migration of dorsally generated neurons, provide strong evidence that D1B neurons arise from $\mathrm{LH}_{2} \mathrm{~A}^{+} / \mathrm{LH}_{2} \mathrm{~B}^{+}$neurons generated at the lateral margins of the $\mathrm{mATH} 1^{+}$progenitor domain.

After E12, the expression of LH2A and LH2B segre gates into distinct neuronal populations in the dorsal spinal cord. At this stage, neurons that emerge from the $\mathrm{mATH} 1^{+}$progenitor domain express $\mathrm{LH} 2 \mathrm{~A}$ but not $\mathrm{LH} 2 \mathrm{~B}$ (Fig. 2J-L). These neurons, defined as D1A neurons, al so appear to migrate ventrally to populate the deep dorsal horn, but settle in a position distinct from that of D1B neurons (Fig. 2J-L; data not shown). The expression of mATH1 overlaps that of the LH2 proteins throughout the period of D1 neuron generation (Fig. 2M-P; data not shown). Thus, both D1A and DIB neurons appear to derive from $\mathrm{mATH}^{+}$progenitors but acquire distinct profiles of transcription factor expression and occupy different positions in the dorsal spinal cord. A third class of dorsal interneurons (termed D2 neurons) expresses the LIM homeobox gene I $\mathrm{SI} 1$ and appears to arise from a more ventral position (Liem et al. 1997).

GDF7 induces the differentiation of dorsal commissural neurons in vitro

To examine whether GDF7 can promote the generation of D1A and D1B interneurons, stage 10 chick intermediate neural plate ([i]) explants (Yamada et al. 1993) were cultured alone or in the presence of GDF7 for 36-48 hr. Explants grown alone did not give rise to $\mathrm{CATH}^{+}$or

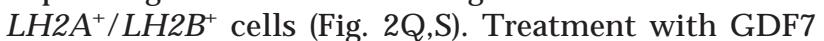
induced $\mathrm{CATHI}^{+}$cells (Fig. 2R) as well as neurons that expressed LH2A and/or LH2B (Fig. 2T). Because the available anti-LH2 antibody detects both $\mathrm{LH} 2 \mathrm{~A}$ and LH2B proteins, we used an RT-PCR assay to distinguish the induction of $\mathrm{LH} 2 \mathrm{~A}$ and $\mathrm{LH} 2 \mathrm{~B}$ gene expression. Treatment of [i] explants with GDF7 induced both LH2A and LH2B (Fig. 2U). Thus, GDF7 induces the expression of transcription factors that define the D1A and D1B classes of interneurons.

Gdf7 mutant mice develop hydrocephal us

To address the requirement for GDF7 function in cell 


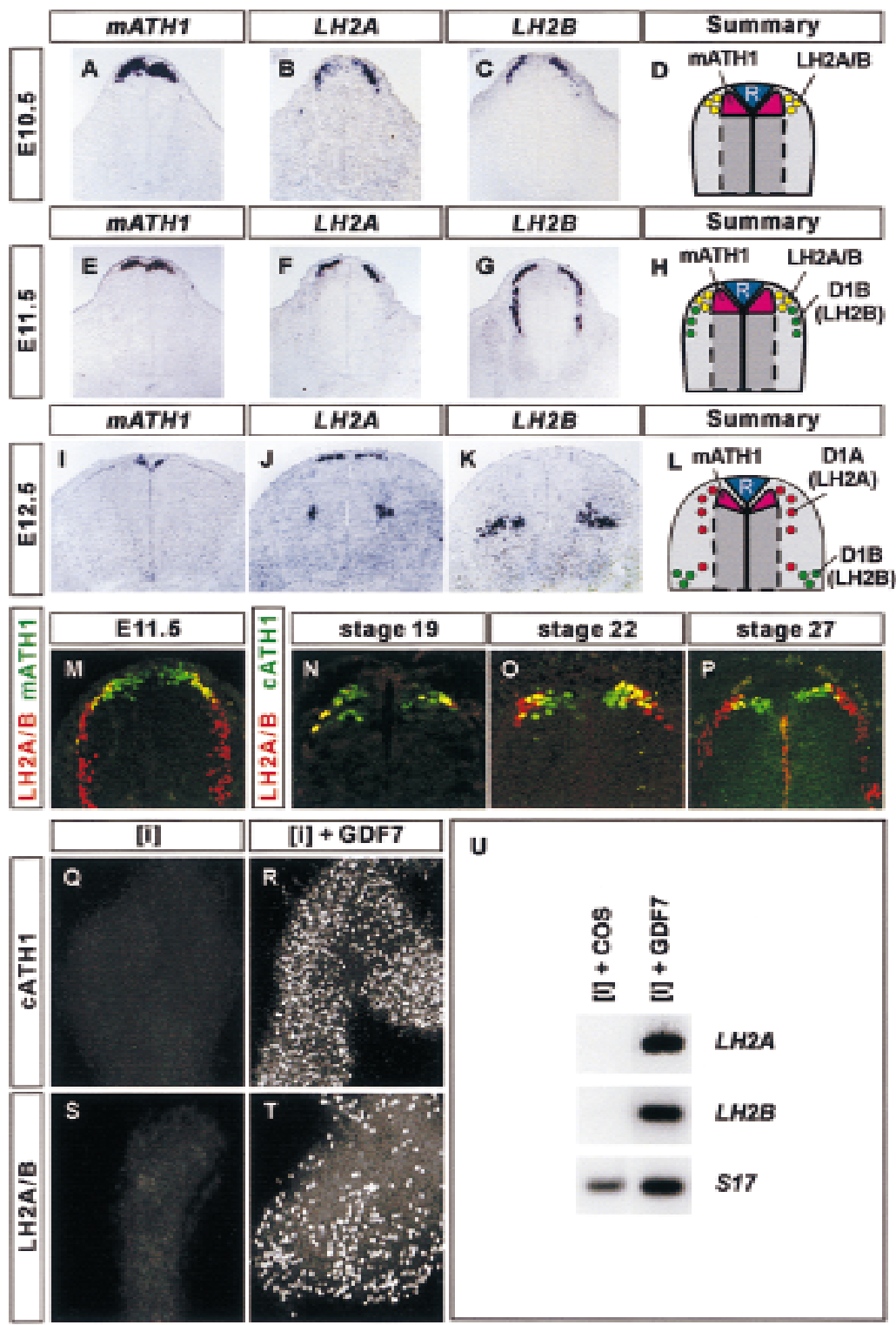

Figure 2. GDF7 promotes the generation of D1A and D1B sensory interneurons. (A-L) In situ hybridization of mouse cervical spinal cord showing the expression of mATH1 $(A, E, I), \operatorname{LH} 2 A(B, F, J)$, and $L H 2 B(C, G, K)$ during the differentiation of dorsal sensory interneurons. At E10.5 (summarized in D), mATH1 (A) is expressed by neural progenitors adjacent to the roof plate. LH2A (B) and LH2B (C) are co-expressed by neurons at the lateral margins of the $\mathrm{mATH} 1^{+}$progenitor domain. At E11.5 (summarized in $\mathrm{H}$ ), co-expression of LH2A (F) and LH2B (G) persists in neurons lateral to the $\mathrm{mATH} 1^{+}$progenitors $(E)$, and a group of more ventrally located D1B neurons express LH2B but not LH2A. At E12.5 (summarized in L), expression of LH2A (J) and LH2B (K) has segregated into distinct neuronal populations. Most D1A neurons, which express LH2A al one, are adjacent to the $\mathrm{mATH} \mathrm{I}^{+}$progenitors (I), whereas D1B neurons, which express LH2B alone, are located in the deep dorsal horn. Expression of $\mathrm{LH} 2 \mathrm{~A}$ and $L H 2 B$ persists in D1A and D1B neurons until roughly E14.5. (M-P) Confocal images showing mATH1/CATH1 (green) and LH2A/LH2B (red) immunoreactivity in the mouse (M) and in the chick (N-P) spinal cord. Double-labeled cells appear yellow. (M) In the E11.5 mouse spinal cord, LH2A/LH2B immunoreactivity is detected in the most lateral $\mathrm{mATH} 1^{+}$progenitors. In the chick spinal cord, lateral $\mathrm{CATH} 1^{+}$progenitors co-express LH2A and/or LH2B at stage $19(\mathrm{~N})$, stage $22(\mathrm{O})$, and stage $27(\mathrm{P})$. Thus, both $\mathrm{D} 1 \mathrm{~A}$ and $\mathrm{D} 1 \mathrm{~B}$ neurons appear to derive from $\mathrm{mATH} 1^{+} / \mathrm{CATH}^{+}$progenitors. (Q , R) Stage 10 chick [i] explants cultured for $48 \mathrm{hr}$ with GDF7 generate $\mathrm{CATH} \mathrm{I}^{+}$neural cells ([i] + control supernatant, 0 cells; [i] +GDF7, $526 \pm 105$ cells; mean \pm S.D., $\mathrm{n}=4-6$ explants). $(\mathrm{S}, \mathrm{T})$ chick [i] explants cultured for $48 \mathrm{hr}$ with GDF7 generate LH2A/LH2B-immunoreactive neurons ([i] + control supernatant, 0 cells; [i] + GDF7, $425 \pm 88$ cells; mean \pm S.D., $n=4-6$ explants). (U ) RT-PCR analysis of LH2A, LH2B, and ribosomal protein S17 gene (control) expression in stage 10 chick [i] explants cultured for 36 hr with COS cell (control) supernatant or supernatant containing GDF7. GDF7 treatment induces expression of both LH2A and LH2B. patterning in the dorsal spinal cord, we generated a null mutation in the mouse Gdf7 gene (Fig. $3 A-C$ ). Mice heterozygous for the targeted Gdf7 allele (termed Gdf $7^{\mathrm{ml}}$ ) were overtly normal and fertile. These mice were interbred to generate homozygous $\mathrm{Gdf} 7^{\mathrm{ml}} / \mathrm{Gdf}^{\mathrm{ml}}$ mutant offspring. In two different genetic backgrounds, Gdf $7^{\mathrm{m} 1}$ homozygous mutant mice were born in normal numbers and survived the immediate postnatal period (Table 1 ).

From 14 to 21 days after birth, however, a significant fraction of the homozygous mutant animals developed severe hydrocephal us (Fig. 3F-I). The penetrance of this phenotype varied between $20 \%$ and $37 \%$, depending on the genetic background (T able 1). Si milar hydrocephal ic abnormalities were not detected in heterozygous $\left(\mathrm{Gdf}^{\mathrm{ml}} /+\right)$ or homozygous wild-type siblings in either genetic background. Further details of the hydrocephal ic phenotype are provided in the legend to Figure 3.

A selective defect in neurogenesis in the dorsal spinal cord of Gdf7 mutant mice

To analyze the role of GDF7-mediated signaling in embryonic neuronal patterning, we examined neural differentiation in the dorsal spinal cord of $\mathrm{Gdf}^{\mathrm{ml}}$ mutant embryos. We first determined whether the development of the roof plate itself is perturbed in $\mathrm{Gdf}^{\mathrm{ml}}$ mutants. The roof plate expression of the homeobox genes Msx1 and MsX2 and the secreted growth factor gene Wnt1 was similar in wild-type and $\mathrm{Gdf}^{\mathrm{ml}}$ homozygous mutant embryos analyzed from E11.5 to E13.5 (Fig. 4A,B; data 
Figure 3. Generation of a Gdf7-null allele and hydrocephalic abnormalities in Gdf7 mutant mice. (A) Strategy for targeted disruption of the mouse Gdf7 locus by homologous recombination. The diagram indicates the position of the Gdf7 exon encoding half of the pro-domain and the entire mature carboxy-terminal region (coding region, solid rectangle; 3' UTR, open rectangle). Restriction sites: (H) HindlII; (R) EcoRV; (S) Sphl; (X) Xbal. (B) Southern blot analysis of DNA from ES clones digested with $X$ bal and EcoRV and probed with the fragment indicated in A. The presence of the wild-type allele is indicated by an $8.5-\mathrm{kb}$ band and the disrupted allele by a 6.9-kb band. (C) PCR analysis of DNA from progeny of heterozygote matings with primers indicated in A. The wild-type allele is indicated by a $130-$ bp band and the mutant al lele by a $260-$ bp band. $(D, E)$ In situ hybridization of wild-type (D) and Gdf7 ${ }^{\mathrm{m} 1}$ homozygous mutant (E) embryos with a Gdf7 coding region probe. Hybridization was not detected in the roof plate in $\mathrm{Gdf}^{\mathrm{ml}}{ }^{1}$ homozygous mutant embryos. (F-I) Parasagittal sections of brains from wild-type $(F, H)$ and $\mathrm{Gdf7}^{\mathrm{m} 1}$ homozygous mutant $(\mathrm{G}, \mathrm{I})$ mice stained with hematoxylin/eosin. Twenty-five percent of Gdf7 mutant brains $(n=8)$ analyzed at postnatal (P) day 15 showed a marked dilation of the lateral ventricles (LV). No obvious defects in morphology of the cerebellum and cerebral cortex were

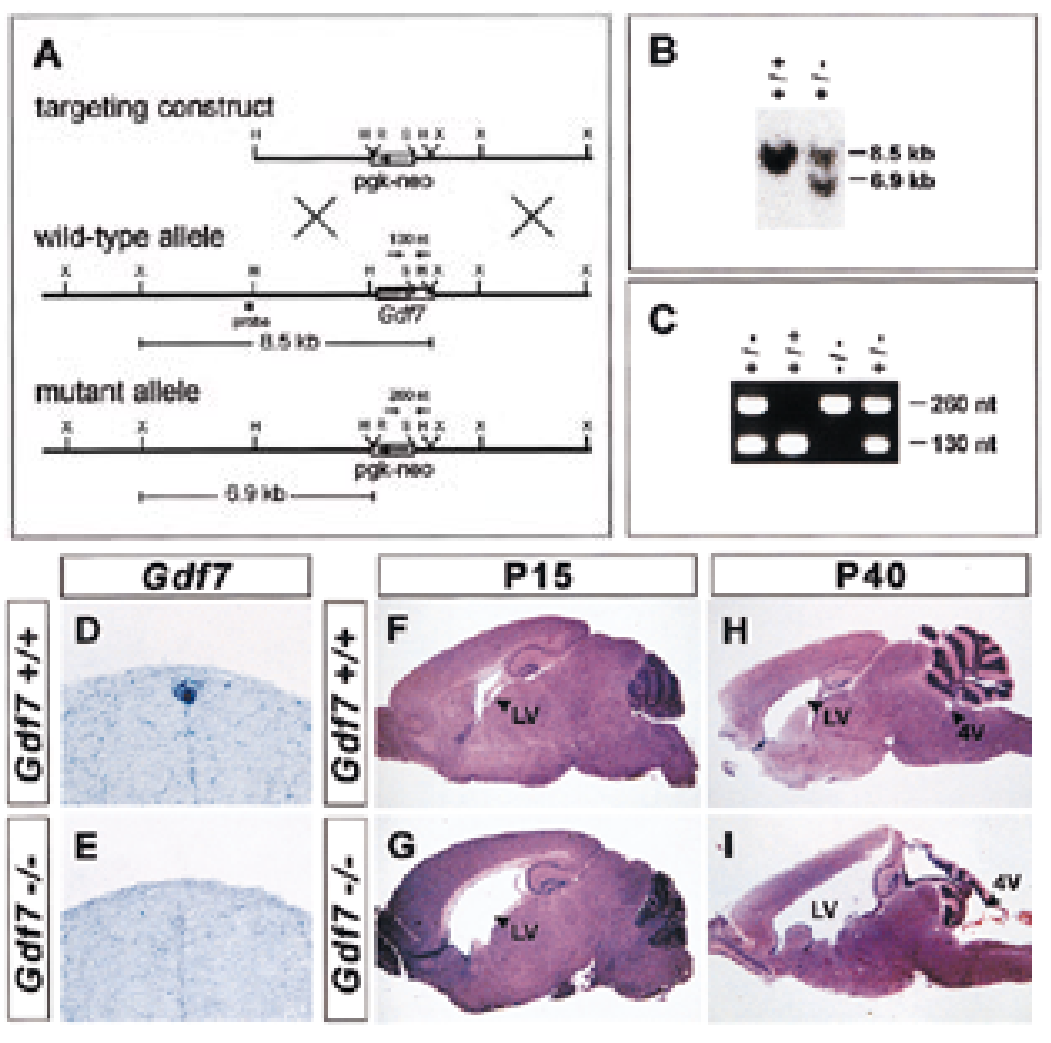
detected at this age. By P40, a severe hydrocephal us that is associated with dilation of the fourth (4V) and lateral ventricles (cf. $\mathrm{H}$ and I) was observed in $25 \%-37 \%$ of Gdf7 mutants (see Table 1). Hydrocephalic mutant animals showed considerable variation in the extent to which the different ventricles were enlarged. In some mutants (I) the fourth ventricle was dilated, and the organization and foliation of the cerebellum was disrupted. In all affected brains examined, however, the cerebral cortex was thinned and the hippocampus was displaced dorsally. Despite these abnormalities, histological analysis showed that the cellular architecture of the cerebellum and cerebral cortex was grossly normal in Gdf7-null mutants (data not shown). The late onset of brain defects and the relatively normal cellular organization in Gdf7 mutants suggest that the disruption of brain morphology is a secondary consequence of hydrocephalus. The expression of Gdf7 in the fourth ventricle choroid plexus (Fig. 1C) raises the possibility that defects in choroid plexus devel opment may underlie the hydrocephal us observed in $\mathrm{Gdf}^{\mathrm{m} 1}$ mutant mice. Histological analysis indicated that the fourth ventricle choroid plexus epithel ium was still present in affected Gdf7m1 mutant mice and expression of Msx1, Bmp6, and Bmp7 in the choroid plexus appeared normal (data not shown). Thus, the cellular basis of the hydrocephal us is unclear, but it is likely to reflect a requirement for Gdf7 function in choroid plexus cells.

not shown). Moreover, the expression of Bmp6 and Bmp7 by roof plate cells was unchanged in $\mathrm{Gdf}^{\mathrm{m} 1} \mathrm{mu}-$ tant embryos examined from E10.5 to E12.5 (Fig. 4C,D;

Table 1. Analysis of progeny from heterozygote matings $\left(\mathrm{Gdf7}^{\mathrm{ml}} /+\times \mathrm{Gdf7} 7^{\mathrm{ml}} /+\right)$

\begin{tabular}{|c|c|c|c|}
\hline$H+$ & $H-$ & $\dashv-$ & $\begin{array}{c}\text { Hydrocephalic }-1- \\
\text { (\% of total } \dashv-\text { ) }\end{array}$ \\
\hline
\end{tabular}

N o. of progeny: mixed background (129Sv $\times$ C57BL/6) $66(26 \%)$ $127(50 \%)$ $60(24 \%)$
$22(37 \%)$

N o. of progeny: inbred background (129Sv)

$15(24 \%)$

$32(52 \%)$

$15(24 \%)$

$3(20 \%)$

Animals were genotyped $\sim 10$ days after birth. No differences were noted in the results of crosses of animals that derive from two independent ES cell targeting events, and both sets of results are combined here. Hydrocephalus was not observed in any wild-type or heterozygous animals in these crosses. data not shown). Thus, the differentiation of the roof plate and its expression of other signaling molecules appear not to be affected by the loss of Gdf7 function.

$\mathrm{N}$ ext, we examined the development of the $\mathrm{mATH}^{+}$ progenitor population in $\mathrm{Gdf}^{\mathrm{ml}}$ mutants and in wildtype and heterozygous siblings. The early phase (E10E10.5) of generation of $\mathrm{MATH} 1^{+}$cells in the dorsal spinal cord appeared normal in $\mathrm{Gdf7}^{\mathrm{ml}}$ mutants (Fig. 4E,H). However, by E11.5, the number of $\mathrm{mATH} 1^{+}$progenitors in $\mathrm{Gdf7}^{\mathrm{ml}}$ mutant embryos was reduced to $40 \%$ (Fig. $4 \mathrm{~F}, \mathrm{H}$ ) and by $\mathrm{E} 12.5$, to $~ 10 \%$ (Fig. 4G, H) of the number found in wild-type embryos. The loss of the later phase of mATH1 expression was a fully penetrant phenotype.

This analysis left unresolved whether the elimination of late mATHI expression in $\mathrm{Gdf}^{\mathrm{ml}}$ mutants reflects the del etion of this progenitor population or simply the loss of an individual molecular marker. To examine this issue, we made use of the observation that $\mathrm{mATH} 1^{+}$cells are normally interposed between $\mathrm{Msx}^{+}$roof plate cells and a more ventral group of progenitor cells defined by 


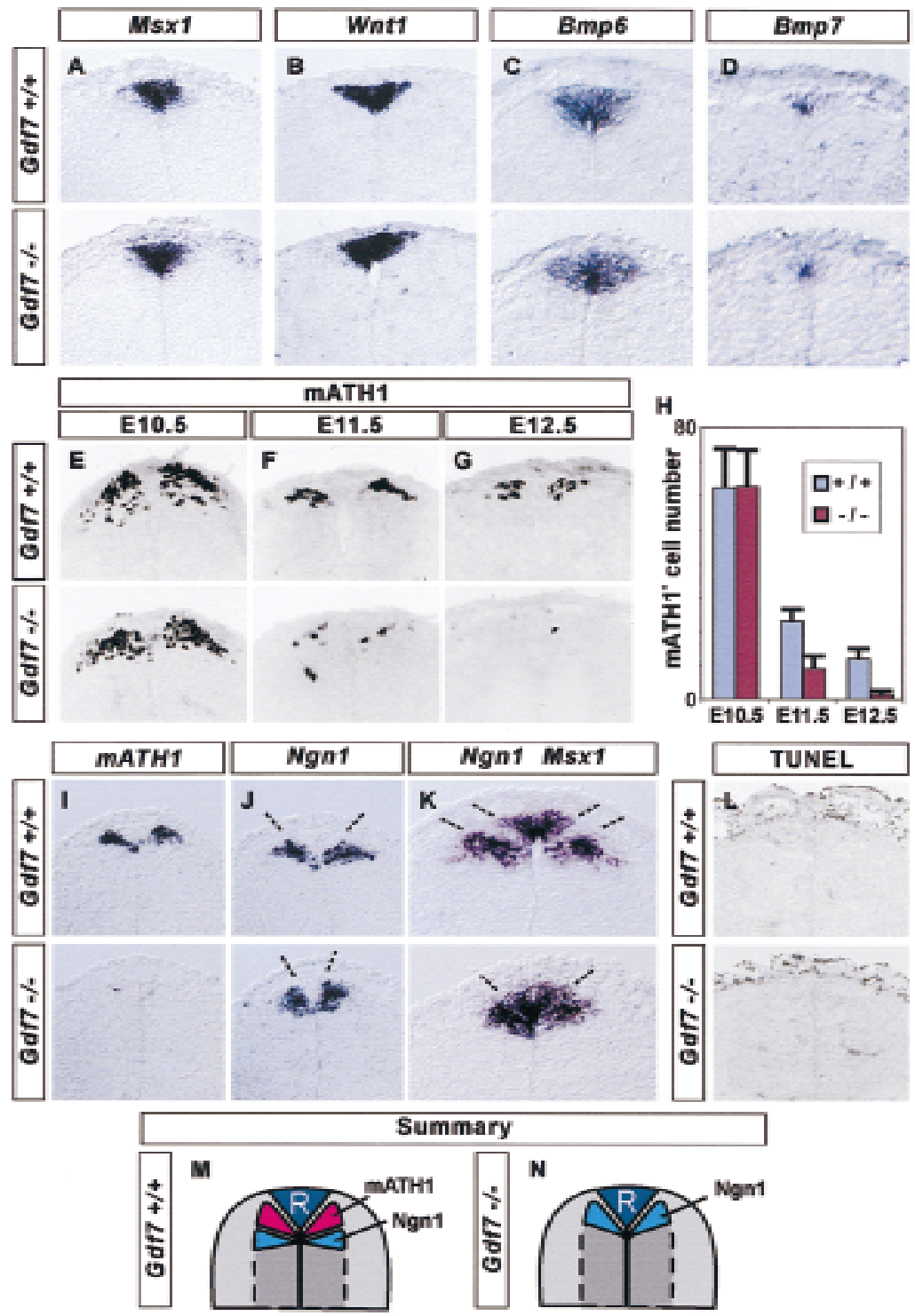

Figure 4. Loss of late $\mathrm{mATH} 1^{+}$progenitors in Gdf7 mutant mice. The development of roof plate cells and dorsal neural progenitors in the cervical (forelimb level) spinal cord in wild-type (top panels) and in Gdf7 ${ }^{\mathrm{ml}}$ homozygous mutant embryos (bottom panels). (A-D) In situ hybridization showing that roof plate expression of Msx1 (A), Wnt1 (B), Bmp6 (C), and Bmp7 (D) is normal in Gdf7 mutant embryos examined at E12.5 (A,B) and at E11.5 (C,D). (E-H) Generation of $\mathrm{mATH}^{+}$progenitors adjacent to the roof plate. At E10.5 $(\mathrm{E}, \mathrm{H})$, mATH $1^{+}$cell number is normal in Gdf7 mutants. By $\mathrm{E} 11.5(\mathrm{~F}, \mathrm{H})$, the number of $\mathrm{mATH}^{+}$cells in Gdf7 mutant embryos is significantly reduced (to $\sim 40 \%$ ), and at E12.5 (G,H), Gdf7 mutants have only $10 \%$ as many $\mathrm{mATH} 1^{+}$cells as wild-type siblings. The depletion of $\mathrm{mATH} 1^{+}$cells in the cervical spinal cord was detected in all E12.5 Gdf7 homozygous mutants examined ( $n=8-20 \mathrm{sec}-$ tions from 18 embryos). (H) Quantitative analysis of the $\mathrm{mATH}^{+}$progenitor population in wildtype and homozygous mutant embryos (mean \pm S.D., $n=10-25$ sections from two to six embryos of each genotype). In addition, we detected no difference in the number of $\mathrm{mATH}^{+}$ progenitors in $\mathrm{Gdf}^{\mathrm{ml}} /$ + heterozygotes as compared with wild-type siblings. (I-K) In situ hybridization showing the location of $\mathrm{mATH}^{+}$and $\mathrm{Ngn}^{+}$cells in wild-type and $\mathrm{Gdf7}^{\mathrm{m} 1}$ mutant embryos at E12.5. In wild-type embryos, $\mathrm{mATH}^{+}$ progenitors (I, top) are interposed between $\mathrm{Ngn}^{+}$ progenitors $(J)$ and $\mathrm{Msx}^{+}$roof plate cells (summarized in $\mathrm{M}$ ). Thus, the $\mathrm{mATH} 1$ progenitor domain appears as a region of unlabeled cells (between broken lines) in the wild-type spinal cord hybridized with $\mathrm{Ngn} 1$ and MsxI probes (K, top). In $\mathrm{Gdf7}^{\mathrm{ml}}$ mutant embryos, the loss of $\mathrm{mATH}^{+}$ cells (I, bottom) is accompanied by a dorsal shift in the position of $\mathrm{NgnI}^{+}$progenitors (J), and the unlabeled region between $\mathrm{Ngnl}^{+}$neural cells and $\mathrm{Msxl}^{+}$roof plate cells is eliminated (K, top, summarized in $\mathrm{N}$ ). The distance between the domains of $\mathrm{Ngn} 1$ progenitors (indicated by broken lines in J) is $89 \pm 14 \mu \mathrm{m}$ in wild-type and $43 \pm 5 \mu \mathrm{m}$ in $\mathrm{Gdf}^{\mathrm{m} 1}$ homozygote embryos (mean \pm S.D.; $n=10$ sections from four embryos of each genotype). There is no difference in the mean width of the $\mathrm{Msxl}^{+}$roof plate in wild-type and mutant embryos (see A). (L) Detection of apoptotic cell death by end labeling of fragmented DNA (TUNEL assay) in the dorsal spinal cord in E12.5 wild-type and Gdf7 ${ }^{\mathrm{m} 1}$ mutant embryos. Very few dying cells are detected in or near the mATH progenitor domain in wild-type embryos or in mutant littermates that lack late mATH $1^{+}$cells. In contrast, abundant cell death was detected in other tissues, for example, in the tail bud and in the distal limb, in both wild-type and mutant embryos (data not shown). (M,N) Summary showing positions of neural progenitors in the dorsal spinal cord in wild-type and $\mathrm{Gdf}^{\mathrm{m} 1}$ mutant embryos at E12.5.

expression of the bHLH gene Neurogenin1 (Ngn1) (Fig. $4 \mathrm{M})$. If the cells that normally express $\mathrm{mATH} 1$ are still present in $\mathrm{Gdf7} \mathrm{F}^{\mathrm{m} 1}$ mutant embryos, we would expect that the $\mathrm{Msxl}^{+}$roof plate cells and the $\mathrm{Ngn}^{+}$progenitors are separated by a domain of cells that express neither gene. Instead we observed that the loss of mATH1 expression (Fig. 4I) was accompanied by a dorsal shift in the $\mathrm{Ngnl}^{+}$cell population to a position immediately adjacent to the roof plate (Fig. 4J-K). The size of the $\mathrm{NgnI}^{+}$ precursor domain in $\mathrm{Gdf7}^{\mathrm{ml}}$ mutants was, however, unchanged (Fig. 4J). These observations show that the late population of $\mathrm{mATH} 1^{+}$progenitor cells is deleted in
Gdf7 ${ }^{\mathrm{m} 1}$ mutants.

To address whether the absence of late $\mathrm{MATH}^{+}$progenitors in $\mathrm{Gdf}^{\mathrm{ml}}$ mutants is a consequence of apoptotic cell death, we compared patterns of cell death in the spinal cord of E12.5 wild-type and mutant embryos. Very few apoptotic cells were detected in the dorsal spinal cord in E12.5 wild-type embryos, and there was no increase in the number of dying cells in $\mathrm{Gdf}^{\mathrm{ml}}{ }^{\mathrm{m}}$ mutant embryos (Fig. 4L). Patterns of cell death were indistinguishable in the cervical or thoracic spinal cord, where the loss of $\mathrm{mATHI}^{+}$cells in $\mathrm{Gdf7}^{\mathrm{ml}}$ mutants is pronounced at E12.5, and at the more developmentally de- 
layed lumbar level, where the loss of $\mathrm{mATH}^{+}$cells was first observed at E13.5. Thus the loss of Gdf7 function does not appear to result in increased apoptosis in the regi on of D1 neuron generation in the dorsal spinal cord.

To address whether the loss of late MATH 1 progenitor cells in $\mathrm{Gdf}^{\mathrm{ml}}$ mutants is accompanied by defects in the generation of dorsal interneurons, we examined the differentiation of D1A and D1B neurons, the two cell populations defined by the differential expression of the LH2 transcription factors. In E11.5 wild-type embryos, LH2A and LH2B are co-expressed by neurons lateral to the roof plate whereas more ventrally, D1B neurons express LH2B but not LH2A (Fig. 5A,B). In Gdf7 ${ }^{\mathrm{m} 1}$ homozygous mutant embryos examined at E11.5, we found no change in expression of LH2A or LH2B (Fig. $5 A, B$ ), in the number of $\mathrm{LH}_{2 \mathrm{~A}^{+}}{ }^{+} \mathrm{LH} 2 \mathrm{~B}^{+}$neurons close to the roof plate (Fig. $5 C, D$ ) or in the number of ventrally located D1B $\left(\mathrm{LH}_{2} \mathrm{~B}^{+} / \mathrm{LH} 2 \mathrm{~A} \rightarrow\right.$ neurons (data not shown).

Older $\mathrm{GdfF}^{\mathrm{ml}}$ mutant embryos, however, exhibit a striking defect in dorsal interneuron generation. In E12.5 wild-type embryos, LH2A and LH2B expression has segregated into two distinct populations of neurons. Most D 1A ( $\mathrm{LH}_{2 \mathrm{~A}}+/ \mathrm{LH} 2 \mathrm{~B} \rightarrow$ ) neurons are located lateral to the roof plate, whereas D1B neurons are found in a more ventral position deep in the dorsal horn (Fig. 5F,J). The number of dorsal D1A neurons in E12.5 Gdf $7^{\mathrm{ml}}$ homo- zygotes was reduced to $~ 8 \%$ of that in wild-type littermates (Fig. 5F-I). In contrast, the number of $\mathrm{LH}_{2 \mathrm{~A}}{ }^{+} \%$ $\mathrm{LH}_{2} \mathrm{~B}^{+}$neurons in the deep dorsal horn, which at E12.5 consist primarily of D1B neurons, was not significantly altered in $\mathrm{Gdf}^{\mathrm{m} 1}$ mutants (Fig. $5 \mathrm{I}-\mathrm{L}$ ). A similar depletion of D1A neurons was seen in $\mathrm{Gdf}^{\mathrm{ml}}$ mutant embryos examined at E13.5 and at E14.5, again with no apparent change in the number of D 1B neurons (data not shown). Several other classes of dorsal cells were also unaffected in $\mathrm{Gdff}^{\mathrm{m} 1}$ mutants, including IsI $1^{+}$(D2) interneurons (wild type, $123 \pm 17$ D2 neurons/section; $\mathrm{Gdf7}^{\mathrm{ml}}$ homozygotes, $106 \pm 13$ D2 neurons/section; mean \pm S.D. for $n=12$ sections of four embryos) and dorsal spinal cord interneurons expressing the LIM homeobox genes $\mathrm{Lmxlb}$ or $\mathrm{Liml} / 2$ (data not shown).

Taken together, these data show that Gdf7 function is required selectively in the pathway of DIA interneuron differentiation.

Other TGF $\beta$-related signals are required for the induction of D1B interneurons

Our analysis of neurogenesis in the dorsal spinal cord of Gdf ${ }^{\mathrm{ml}}$ mutant embryos indicates that the generation of D1B neurons does not require GDF7 signal ing. Previous studies have demonstrated that the ability of chick roof
Figure5. A selective loss of D1A neurons in Gdf7 mutant mice. Analysis of dorsal neuron populations in the cervical (forelimb level) spinal cord in wild-type embryos (top panels) and in Gdf7 ${ }^{\mathrm{m} 1}$ homozygous mutant embryos (bottom panels). (AE) D1 neuron populations in the E11.5 spinal cord (summarized in E). In situ hybridization shows that at this stage, expression of LH2A (A) and LH2B (B) is normal in Gdf7 mutant embryos. The number of dorsal LH2A/LH2B-immunoreactive neurons (red box in $C$ ) is not changed in Gdf7 mutants. (D) Quantitative analysis of the dorsal $\mathrm{LH}_{2} \mathrm{~A}^{+} / \mathrm{LH}_{2} \mathrm{~B}^{+}$cell population (mean \pm S.D., $\mathrm{n}=10-25$ sections from two to six embryos of each genotype). We also found no alteration in the number of more ventrally located D1B neurons in $\mathrm{Gdf}^{\mathrm{m} 1}$ mutants. (F-M) D1 neuron populations at E12.5 (summarized in M). At this stage, expression of LH2A (F) is greatly reduced, whereas LH2B ( ) is unaffected in Gdf7 mutant embryos. Similarly, the number of dorsal LH2A/LH2B-immunoreactive cells (DIA neurons; boxed in I, shown enlarged in $\mathrm{G}$ ) is reduced to $\sim 8 \%$ the number in wild-type and the number of ventral LH2A/LH2B-immunoreactive cells (mostly D1B neurons; boxed in I, enlarged in $\mathrm{K}$ ) is not significantly al tered in Gdf7 mutants. $(H, L)$ Quantitative analysis of the D1A and D1B cell populations (mean \pm S.D., $\mathrm{n}=10-25$ sections from two to six embryos of each genotype).
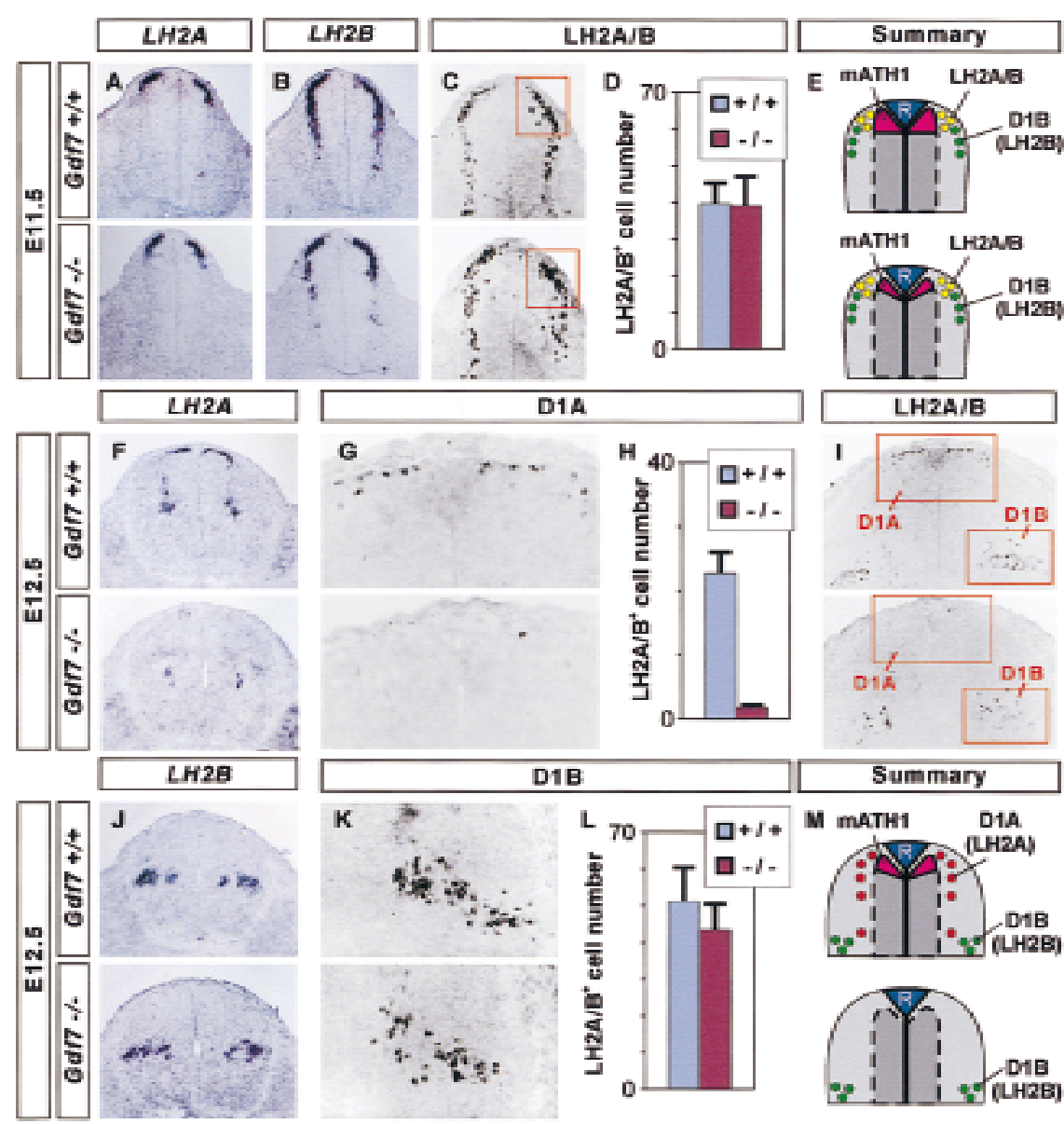


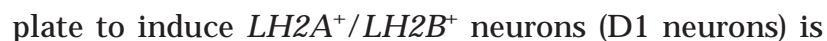
blocked only partially by treatment with the BMP binding proteins Noggin and Follistatin (Liem et al. 1997). This partial block could reflect the expression by the chick roof plate of TGF $\beta$ family members such as Dsl-1 that are insensitive to N oggin and Follistatin (Liem et al . 1997) or that some D1 neurons can be induced by nonTGF $\beta$ signals from the roof plate.

To begin to address whether the generation of $D 1 B$ neurons depends on inductive signals mediated by other T GF $\beta$ family members, we examined whether the inductive activities of the three known BMPs expressed by mouse roof plate cells can be inhibited by BMP-binding proteins. Noggin binds and inactivates BM P4 (Zimmerman et al. 1996) and Follistatin blocks signaling by activin and BM P7 (N akamura et al. 1990; Yamashita et al. 1995). We found that the GDF7-mediated induction of $\mathrm{LH}_{2 \mathrm{~A}} / \mathrm{LH}_{2 \mathrm{~B}}{ }^{+}$neurons in chick [i] explants was blocked by $\mathrm{N}$ oggin but not by Follistatin (Fig. 6A). Exposure of [i] explants to either BMP6 (Fig. 6B) or BMP7 (Liem et al . 1997) al so induced $\mathrm{LH}_{2} \mathrm{~A} / \mathrm{LH}_{2} \mathrm{~B}^{+}$neurons. The activity of BM P6 and BM P7 in these assays, in contrast to that of GDF7, was blocked by Follistatin but not by N oggin (Fig. 6B; Liem et al . 1997). Thus, the three known BM P family members expressed by the mouse roof pl ate are sensitive to the inhibitory actions of either $\mathrm{N}$ oggin or Follistatin.

$\mathrm{N}$ ext, we examined whether inductive signals from mouse roof plate that promote $\mathrm{LH}_{2 \mathrm{~A}} / \mathrm{LH}_{2} \mathrm{~B}^{+}$neuron generation are inhibited by $\mathrm{N}$ oggin and Follistatin. Many $\mathrm{LH}_{2} \mathrm{~A} / \mathrm{LH}_{2} \mathrm{~B}^{+}$neurons were induced in [i] explants grown in contact with mouse roof plate (Fig. 6D,F). The induction of $\mathrm{LH} 2 \mathrm{~A} / \mathrm{LH}_{2} \mathrm{~B}^{+}$neurons by the roof plate was markedl y suppressed by treatment with either $\mathrm{N}$ oggin or Follistatin and was inhibited by $\sim 97 \%$ with combined application of both antagonists (Fig. 6E,F). Thus, the generation of both the DIA and D1B classes of neurons in response to roof plate signals appears to depend on inductive signaling mediated by TGF $\beta$ family members. The persistence of D1B neuronal differentiation in $\mathrm{Gdf7}^{\mathrm{m} 1}$ mutant embryos is therefore likely to result from residual TGF $\beta$-related signaling by the roof plate.

The generation of DIA neurons in Gdf7 mutants is restored by exogenous GDF7 or BMP7

Our results indicate that GDF7 has an essential signaling function in the generation of D1A neurons. However, both Bmp6 and Bmp7 are expressed normally by roof plate cells in $G d f 7^{\mathrm{ml}}$ mutants (Fig. 4C,D), raising the issue of why BMP6 and BM P7 fail to compensate for the loss of GDF7 activity in vivo. One possible explanation is that in mouse neural tissue, GDF7 al one is capable of promoting D1A neuron formation. To test this idea, we compared the ability of GDF7 and BM P7 to induceD 1A neurons in wild-type neural tissue and to rescue D1A neuron generation in neural tissue isolated from $\mathrm{Gdf7}{ }^{\mathrm{ml}}$ mutant embryos.

First, we asked whether exogenous GDF7 can restore late MATH1 and LH2A expression, the two markers of DIA neuron differentiation, in $\mathrm{Gdff}^{\mathrm{m} 1}$ mutant neural

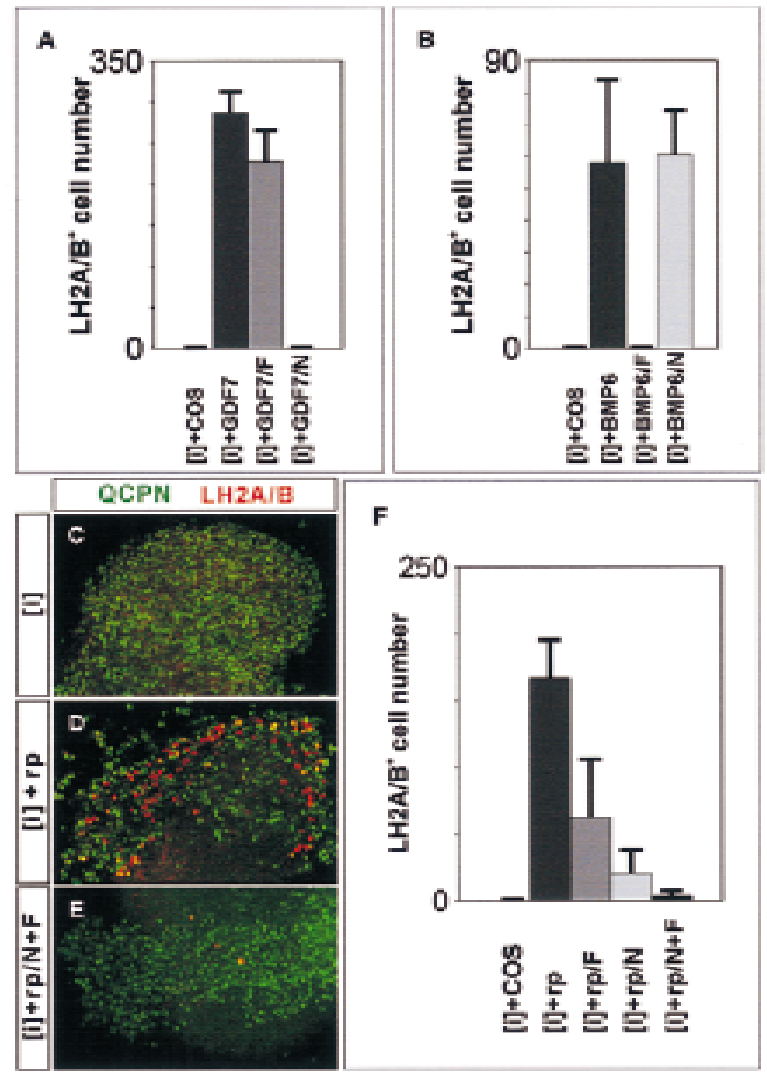

Figure 6. Roof plate induction of $D 1 A$ and $D 1 B$ neurons requires TGF $\beta$-related signaling. (A) GDF7 induction of LH2A/ $\mathrm{LH}_{2 \mathrm{~B}^{+}}$neurons in chick [i] explants is blocked by addition of Noggin (N ; $20 \mathrm{~nm}$ ) but not by Follistatin (F; $80 \mathrm{~nm}$ ). (B) Follistatin, but not $\mathrm{N}$ oggin, blocks the BM P6-mediated induction of $\mathrm{LH}_{2 \mathrm{~A}} / \mathrm{LH}_{2} \mathrm{~B}^{+}$neurons. (C-E) Quail neural plate [i] explants [stained with anti-quail cell-specific perinuclear marker (QCPN), green] cultured alone (C) for $48 \mathrm{hr}$ do not generate $\mathrm{LH} 2 \mathrm{~A} / \mathrm{LH}_{2} \mathrm{~B}^{+}$neurons (red), whereas explants cultured with mouse roof plate (D) generate many $\mathrm{LH} 2 \mathrm{~A} / \mathrm{LH}_{2} \mathrm{~B}^{+}$neurons. Addition of $\mathrm{N}$ oggin al one (20 nM) or Follistatin al one (80 nM) partially blocks the induction of $\mathrm{LH} 2 \mathrm{~A} / \mathrm{LH}_{2} \mathrm{~B}^{+}$neurons by mouse roof plate $(\mathrm{F})$. Addition of both $\mathrm{N}$ oggin and Follistatin reduces mouse roof plate-mediated induction of $\mathrm{LH} 2 \mathrm{~A} / \mathrm{LH}_{2} \mathrm{~B}^{+}$neurons by $\sim 95 \%(E, F)$. Histograms show mean \pm S.D. for $6-12$ explants.

tissue. Explants of mouse dorsal neural tube containing roof plate cells ([d+rp] explants) were isolated from $\mathrm{Gdf7}^{\mathrm{m} 1}$ homozygous mutants and wild-type siblings at E11.5, a time when a reduction in MATH 1 expression is first detected in mutant embryos. These explants were cultured for $60 \mathrm{hr}$, either alone or in the presence of GDF7. When cultured alone, Gdf7 ${ }^{\mathrm{m} 1}$ mutant [d+rp] explants generated only $\sim 10 \%$ as many $\mathrm{mATH} 1^{+}$cells as wild-type [d+rp] explants (Fig. 7A,B,G), consistent with the loss of late $\mathrm{mATH} 1^{+}$cells in $\mathrm{Gdf}^{\mathrm{ml}}$ mutants in vivo. Moreover, there was a threefold reduction in LH2A expression in [d+rp] explants from Gdf7 ${ }^{\mathrm{ml}}$ mutants, relative to the level detected in wild-type explants (Fig. $7 \mathrm{H}$ ). Addition of GDF7 to wild-type [d+rp] explants resulted in a marked increase in the number of $\mathrm{mATH} 1^{+}$cells 
Figure 7. Treatment with Gdf7 or BMP7 restores $M A T H 1$ and LH2A expression in Gdf7 mutant neural tissue. (A-F) Expression of mATH1 (red) in explants of mouse forel imb level dorsal neural tube ([d+rp] explants) isolated from wildtype $(A, C, E)$ and $G d f 7^{m 1}$ homozygous mutant $(B, D, F)$ embryos. M sx $1^{+}$roof plate cells are green. Gdf7 mutant [d+rp] explants isolated at E11.5 (44 somites) (B) and cultured in COS (control) supernatant for $60 \mathrm{hr}$ generate $<10 \%$ as many $\mathrm{mATH} \mathrm{I}^{+}$cells as explants from age-matched wild-type siblings (A,G). Wild-type explants respond to added GDF7 with the generation of $\sim 5$-fold more $\mathrm{mATH} 1^{+}$ cells $(C, G)$. Culture with GDF7 increases the number of $\mathrm{mATH} 1^{+}$cells in mutant explants to a level similar to that in treated wild-type explants $(D, G)$. Treatment with BMP7 similarly increases MATH1 cell number in wild-type and mutant explants $(E, F, G)$. In these experiments, explants were treated with equivalent doses of GDF7 and BMP7, as judged by their activity in inducing $\mathrm{LH}_{2} \mathrm{~A}^{+} / \mathrm{LH}_{2} \mathrm{~B}^{+}$neurons in chick neural plate assays (data not shown). In untreated wild-type and mutant [d+rp] explants, $\mathrm{mATH} 1^{+}$cells are restricted to the region adjacent to the roof plate $(A, B)$. After treatment with GDF7 or BMP7, $\mathrm{mATH} 1^{+}$cells are found at all dorsoventral positions within the explants, independent of genotype (C-F). Thus, at E11.5, cells more distant from the roof plate respond to GDF7 or BM P7 with the expression of MATH1. GDF7 treatment of [d+rp] explants isolated from E12.5 wild-type or mutant embryos did not increase $\mathrm{mATH}^{+}$cell number (data not shown), suggesting that GDF7 signaling normally acts prior to E12.5 to induce or maintain $\mathrm{mATH} 1^{+}$progenitors. (G) Histograms show mean \pm S.D. of results from four to six explants of each genotype. (H) RT-PCR analysis of LH2A and ribosomal protein S12 gene (control) expression in E11.5 wild-type and Gdf7 mutant [d+rp] explants cultured for $60 \mathrm{hr}$ with COS cell (control) supernatant or supernatant containing GDF7 or BMP7. Treatment of mutant explants with GDF7 or BMP7 restores LH2A expression to wild-type levels.

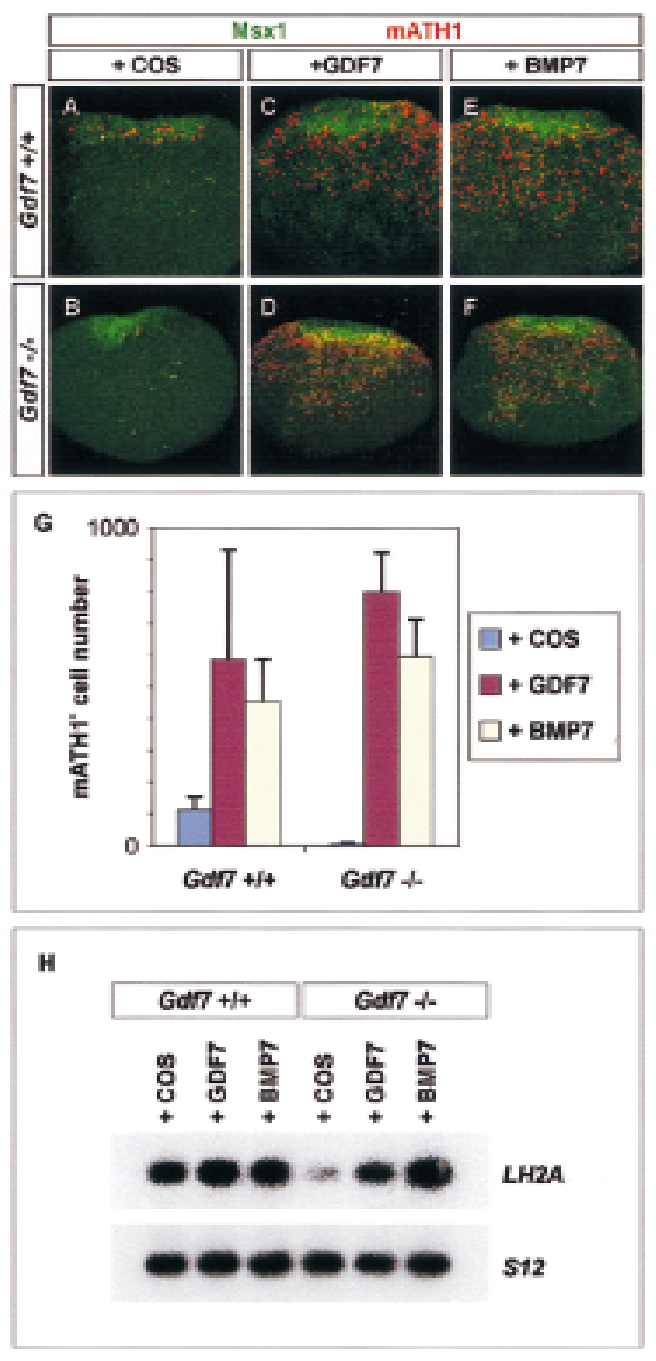

(Fig. 7C,G). GDF7 treatment of Gdf7m1 mutant [d+rp] explants increased the number of $\mathrm{mATH} 1^{+}$cells to a level similar to that in treated wild-type explants (Fig. $7 D, G)$ and restored LH2A expression to wildtype levels (Fig. 7H). Thus, GDF7 treatment of [d+rp] explants isolated from E11.5 Gdf7 ${ }^{\mathrm{ml}}$ mutant embryos rescues the late phases of both MATH 1 and LH2A expression.

To examine whether other BM Ps expressed by the roof plate mimic the ability of GDF7 to restore late MATH 1 and LH2A expression, wild-type or Gdf7 ${ }^{\mathrm{ml}}$ mutant explants were cultured in the presence of BM P7. This treatment increased $\mathrm{mATH}^{+}$cell number to a level similar to that obtained with GDF7 (Fig. 7E,F,G). In addition, exposure of $\mathrm{Gdf} 7^{\mathrm{m} 1}$ mutant explants to BM P7 restored LH2A expression to wild-type levels (Fig. 7H). Thus, there is no apparent difference in the ability of GDF7 and BM P7, or by inference BM P6, to rescue late $\mathrm{MATH} 1$ and LH2A expression in $\mathrm{Gdf}^{\mathrm{m} 1}$ mutant explants. These results argue against the idea that the selective requirement for GDF7 function in the generation of D1A neurons results from the inability of neural progenitor cells to respond to BM P6 and BM P7.

\section{Discussion}

BM Ps have been implicated in the induction and patterning of neuronal cell types in the dorsal spinal cord but their precise functions in this process have not been establi shed. We have examined whether BM Ps are requi red in vivo to promote the differentiation of dorsal interneurons and whether different BM Ps have redundant or distinct functions in the generation of specific dorsal cell types. Our results show that Gdf7-null mutant micelack a single identified class of dorsal commissural neurons, D1A neurons, and thus establish that BM P-mediated signals from the roof plate are required for the differentiation of specific neuronal subtypes in the dorsal spinal cord. Furthermore, our studies provide evidence that the multiple BM Ps expressed by the roof plate do indeed have nonredundant functions in controlling the generation of sel ective subsets of spinal neurons. The diversity of TGF $\beta$-related molecules expressed in discrete regions within the embryonic CNS thus raises the possibility that this class of signal s is employed more widely in the specification of neuronal subtype identity. 
GDF7 is required for the generation of D1A interneurons

Genetic studies on the function of other vertebrate BM P family members have established certain essential roles for this class of secreted proteins, but have not resolved their contribution, if any, to the control of neuronal identity. Targeted mutations in mouse Bmp2 and Bmp4 result in early embryonic lethality, which has so far precluded an analysis of their later function in neuronal development (Winnier et al. 1995; Zhang and Bradley 1996). Eye growth and development is perturbed in Bmp7 mutants (Dudley et al. 1995; Luo et al. 1995) but neuronal patterning defects in the brain and spinal cord have not been reported. Mutations of other BMP family members appear not to be associated with neural abnormalities (King et al. 1994; Storm et al. 1994). One interpretation of these results is that there is functional redundancy between co-expressed BM $P$ family members (Dudley and Robertson 1997). Alternatively, the BMPs that have been analyzed to date may not play essential roles in the particular neural structures that have been studied. Our results establish that GDF7 has a critical function in the devel opment of a specific subset of dorsal spinal cord interneurons and thus provide genetic evidence for the involvement of BM P signaling in the control of neuronal identity and pattern.

The expression of Bmp6 and Bmp7 by roof plate cells is not changed in Gdf7 mutants. Therefore, the loss of DIA neurons in Gdf7 mutants could reflect a specific requirement for GDF7 signaling. Alternatively, the inductive activity of GDF7 and other roof-plate-derived BM Ps could be equival ent, with the diffusion of multiple BMPs from the roof plate establishing a BMP activity gradient in the dorsal neural tube. If the specification of D1A neurons were to require the highest level of BM P activity, the loss of GDF7 function might simply reduce net BM P activity to a level below the threshold sufficient to generate D1A neurons. An examination of dorsal neuronal patterning in Bmp6 and Bmp7 mutants has, however, reveal ed no apparent defect in the differentiation of D1A or D1B neurons (K.J. Lee, T.M. Jessell, A. Dudley, M. Solloway, and E. Robertson, unpubl.). Thus, the loss of D1A interneurons in Gdf7 mutants is most easily explai ned by a selective dependence on GDF7 signaling, in turn indicating that roof-plate-derived BM Ps have nonequivalent functions in vivo.

It remains unclear why Bmp6 and Bmp7 fail to substitute for Gdf7 in vivo. The specific requi rement for GDF7 could result either from sel ectivity in the ability of these BM Ps to promote D1A neuron generation or from a difference in the presentation of these signaling molecules in vivo. We find that D1A neuron generation can be restored in $\mathrm{Gdf}^{\mathrm{ml}}$ mutant explants by treatment with either GDF7 or BM P7. Si milarly, GDF7, BM P6, and BM P7 have indistingui shable inductive activities on chick neural tissue. Thus, the exposure of neural tissue to recombinant BM Ps in vitro appears to obscure the distinction in the functions of GDF7 and other roof-plate-derived BM Ps in vivo.
GDF7, BMP6, and BMP7 have apparently similar activities on cultured neural tissue, yet serve different functions in vivo. One possible explanation for this observation is that although Bmp6 and Bmp7 are expressed by roof-platecells, the level of BM P6 and BM P7 produced is below the threshold for D1A neuron generation. A second possibility is that the activities of BM Ps in vivo require accessory factors that are available in the vicinity of the roof plate only for GDF7. One potential class of accessory factor may be a BM $P$ heterodimer partner that enhances inductive activity (Aono et al. 1995; Suzuki et al. 1997), and the roof plate might express such a factor that dimerizes with GDF7, but not with other BMPs. A second class of accessory factor might be one required to facilitate the secretion, diffusion, or presentation of BMPs. The Drosophila BMP-binding protein Sog has been suggested to function in vivo not simply as a BMP antagonist, but rather as part of a transport mechanism for the BMP family member Dpp (Holley et al. 1996). Indeed, Noggin, a protein that we have found to bind GDF7 but not BMP6 and BMP7, is expressed by roofplate cells (Shimamura et al. 1995; McMahon et al. 1998). It is possible, therefore, that N oggin facilitates the diffusion or presentation of GDF7, and the failure of BM P6 and BMP7 to substitute for GDF7 reflects the absence of corresponding accessory factors for these BM Ps. Mice lacking Noggin function have defects in ventral neural tube patterning (McMahon et al. 1998), but the differentiation of dorsal interneurons has not been analyzed in these mutants.

The generation of other classes of dorsal interneurons depends on TGF $\beta$-related signals independent of GDF7

The generation of D1B neurons is unaffected in $\mathrm{Gdf7}^{\mathrm{ml}}$ mutants, indicating that other signals are sufficient for D1B neuron generation. One likely source of signals that direct D1B neuron generation is the roof plate. In addition, because D1B neurons are generated prior to D1A neurons, earlier BMP signals produced by epidermal ectoderm cells (Liem et al. 1995; Lyons et al . 1995; Dudley and Robertson 1997) may also contribute to the generation of D1B neurons. The induction of $\mathrm{LH}_{2} \mathrm{~A} / \mathrm{LH}_{2} \mathrm{~B}^{+}$ neurons by roof-plate cells (Fig. 6) and by epidermal ectoderm (Liem et al. 1997) is blocked by treatment with Follistatin and Noggin. Thus, inductive signals for D1B neuron differentiation, whether provided by the roof plate or by the epidermal ectoderm, appear to be mediated by TGF $\beta$ family members.

Other classes of dorsal interneurons, notably D 2 interneurons, also differentiate normally in the absence of GDF7 function. A different TGF $\beta$-related protein, activinB, has been implicated in the induction of D2 interneurons (Liem et al. 1997). Members of different subclasses of the TGF $\beta$ superfamily can also act as qualitatively distinct signals in the promotion of diverse neural crest derivatives (Shah et al. 1996). Collectively, these observations support the idea that the activities of distinct TGF $\beta$ family members contribute to the diversifi- 
cation of cell types in both the central and peripheral nervous systems.

GDF7 signaling and the pathway of D1 interneuron specification

Our results indicate that the loss of mATH 1 expression reflects the deletion of the neuronal progenitors normally marked by MATH1. It follows that the DIA neurons that normal ly derive from these progenitors are al so lacking. The el imination of the late $\mathrm{mATH}^{+}$cells does not appear to result from apoptosis of these dorsal neural progenitors as no increase in cell death was observed in the dorsal spinal cord in $\mathrm{Gdf}^{\mathrm{m} 1}$ mutants. In addition, we found no increase in the $\mathrm{NgnI}^{+}$population or in the number of D1B or D2 interneurons in Gdf7 mutants. Thus, the loss of $\mathrm{mATH} 1^{+}$cells and DIA neurons is likely to result from a failure in the generation of this cell population rather than from cell death or from a switch in cell fate.

There are two possible steps at which GDF7 may influence the differentiation of D1 interneurons. N either the initial generation of $\mathrm{MATH} 1^{+}$progenitors in the dorsal neural tube nor the differentiation of D1B interneurons from these progenitors is affected by loss of GDF7 function. In contrast, the maintenance of the $\mathrm{mATH} 1^{+}$ progenitor population and the differentiation of D1A neurons from this late population of $\mathrm{MATH}^{+}$progenitors depends on GDF7 signaling. Thus, GDF7 activity could be required to induce late $\mathrm{mATH} 1^{+}$progenitors from the pool of dorsal Pax $3^{+}$, Pax $7^{+}$precursors (Fig. 8, Model 1). Alternatively, GDF7 could be required for the conversion of early D1B neuron-producing $\mathrm{mATH}^{+}$

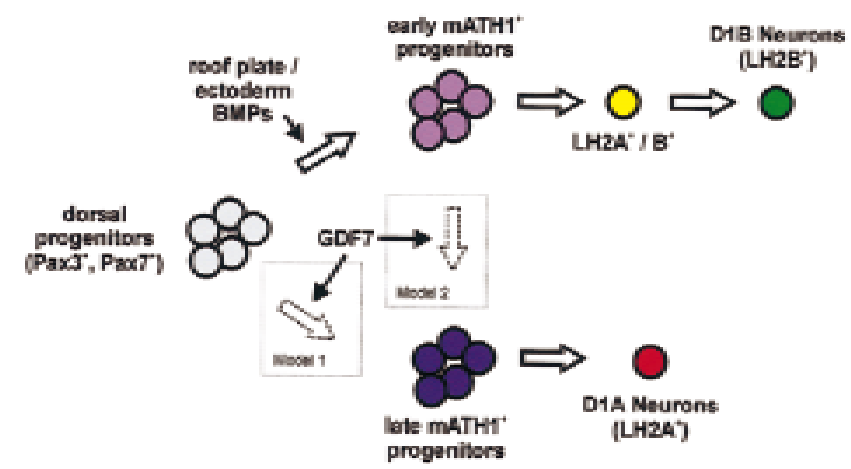

Figure 8. Potential roles for GDF7 in the regulation of interneuron fate in the dorsal spinal cord. The generation of late $\mathrm{mATH} 1^{+}$progenitors and DIA neurons depends on GDF7 activity. In contrast, other BM P signals from the epidermal ectoderm and/or roof plate appear to be sufficient for the induction of early $\mathrm{mATH}^{+}$progenitors and the differentiation of $\mathrm{DlB}$ neurons. GDF7 could function in the generation of D1A neurons in one of two ways: GDF7 may act on dorsal $\mathrm{Pax}^{+}, \mathrm{Pax}^{+}$ neural plate cells to induce the late population of $\mathrm{mATH} 1^{+}$progenitors that differentiate into D1A neurons (Model 1). Alternatively, GDF7 may be required to convert the early D1B-fated $\mathrm{mATH} 1^{+}$progenitors into the late class of $\mathrm{mATH} 1^{+}$progenitors that generates D1A neurons (Model 2). cells to a second $\mathrm{mATH} 1^{+}$progenitor cell type that gives rise instead to D1A neurons (Fig. 8, Model 2).

An essential role for the roof plate as a secondary signaling center

The patterning of cell types in both the dorsal and ventral halves of the spinal cord appears to involve a cascade of inductive signaling initiated in adjacent non-neural tissue and propagated by midline glial cells (Tanabe and Jessell 1996). Ventrally, Shh secreted by the notochord induces floor plate cells, thereby establishing a secondary, neural source of Shh. Shh function is required for ventral cell patterning in the spinal cord ( $M$ arti et al. 1995; Chiang et al. 1996; Ericson et al. 1996). However, it remains unclear whether early Shh signaling by the notochord and late Shh signaling by the floor plate have separate rol es in the patterning of the ventral spi nal cord.

In the dorsal spinal cord, BM Ps produced by cells of the epidermal ectoderm induce roof-plate cells, which in turn express additional BM Ps (Liem et al. 1997). Inductive signal ing in the dorsal neural tube, however, appears to differ from that in the ventral neural tube, in that certain BM Ps such as Gdf7 are expressed solely by roofplate cells and not by the epidermal ectoderm. Our genetic analysis of GDF7 function has established a requirement for roof-platederived signals in the differentiation of one subclass of dorsal interneurons. Thus, primary and secondary dorsal signaling centers, the epidermal ectoderm and roof plate, have distinct roles in the regulation of neuronal identity and pattern in the mammalian CNS.

\section{Materials and methods}

Cloning of chick and human Gdf7-related genes

A 75-nucleotide fragment of chick GDF6/7 was cloned by degenerate PCR with the primers: $5^{\prime}$-CCGCTGGATTACGAGGCATAC-3' and 5'-GTTGGTGGGCTCCAGGTGGG-3'. This fragment was used to screen a chicken genomic DNA library (Stratagene), and two overlapping clones were isolated and mapped. A fragment of human GDF7 (gift of Se-Jin Lee) was used to isolate overlapping clones from a human genomic DN A library. Human GDF7 was mapped by FISH (BIOS Labs) to 2p23$2 \mathrm{p} 24$, a position that is syntenic to that reported previously for mouse Gdf7 on the proximal end of chromosome 12 (Storm et al. 1994).

\section{Generation of a targeted mutation in Gdf7}

A mouse 129/Sv genomic library (Stratagene) was screened with a 400-nucleotide Gdf7 genomic fragment (Storm et al. 1994), and overlapping phage clones were isolated and mapped (Fig. 3). The Gdf7 targeting vector was constructed by flanking pgk-neo with a 3.5-kb HindllI fragment and a 5.5-kb Sphl-N otl fragment (where the $\mathrm{N}$ otl site is provided by the phage $\lambda$ polylinker). This targeting vector is designed to delete the Gdf7 exon that encodes half of the propeptide and the mature carboxy-terminal domain. Linearized plasmid $(30 \mu \mathrm{g})$ was used to electroporate $3 \times 10^{7}$ E14 ES cells (Hooper et al. 1987) at $800 \mathrm{~V}$ and $3 \mu \mathrm{F}$ with a BioRad Gene Pulser. One hundred and sixty G418-resistant 
colonies were isolated and expanded. Genomic DNA was prepared and digested with Xbal and EcoRV and probed with a 200-nucleotide Smal fragment. Six recombinant clones were identified and confirmed by further Southern bl ot analysis. Two of these clones were injected into C57BL/6J blastocysts to produce a total of three chimeric founders that transmitted the mutated allele.

Indistinguishable phenotypes were observed in animals derived from the independently targeted clones, both in a mixed (129Sv ×C57B/6) and an inbred (129Sv) background. Genotyping of embryos and offspring was performed by PCR with the following primers: Neo220, 5'-ACTTCCTGACTAGGGGAGGAG-3'; GDF-C3, 5'-ATTCTCTACATCGATGCCGCC-3'; KO-B1, 5'-ATGACACCTGCTCTTGAGCTAGGG-3'. Thirtythree cycles of PCR were performed with annealing at $65^{\circ} \mathrm{C}$. The mutant al lele generated a 260 -nucl eotide product (between $\mathrm{NeO220}$ and KO-B1) and the wild-type allele a 130-nucleotide product (between GDF-C3 and KO-B1).

\section{In situ hybridization}

In situ hybridization was performed essentially as described (Schaeren-Wiemers and Gerfin-Moser 1993). For detection of mouse Gdf7, a 400-nucleotide genomic fragment (Storm et al. 1994) or a 1.2-kb Hindlll fragment was used as a probe. A 5-kb Xbal genomic fragment was used to detect chick GDF6/7. Other probes for in situ hybridization were Bmp2 and Bmp6 (Lyons et al. 1989), Bmp4 (Jones et al. 1991), Bmp5 (King et al. 1994), Bmp7 (Lyons et al. 1995), Gdf5 and Gdf6 (Storm et al. 1994), mouse Dsl 1 (Basler et al. 1993), mATH1 (Helms and Johnson 1998), rat LH2A (Xu et al. 1993), mouse LH2B [gift of L. Carlsson (Umeå University, Sweden) and H. Okamoto (Keio University School of M edicine, Japan)], chick LH2A (gift of J.C. Izpisua-Belmonte, Salk Institute, La Jolla, CA), chick LH2B (Liem et al. 1997), Wnt1 (Parr et al. 1993), Msx1 (M acKenzie et al. 1991), Msx2 (M onaghan et al. 1991), Ngn1 (Ma et al. 1996), and LmxIb (Chen et al. 1998).

\section{Immunofluoresence and cell death (TU NEL) assays}

Immunocytochemistry was performed as described ( $Y$ amada et al. 1993; Pfaff et al. 1996). Antibodies used were: L1, rabbit anti-LH2A/LH2B (Liem et al. 1997); mouse anti-LH2A/LH2B (G. Tremml and T.M. Jessell, unpubl.), guinea pig anti-LH2B (K.J. Lee and T.M. Jessell, unpubl.); anti-mATH1/CATH 1 (Helms and Johnson 1998); K5, anti-Isl 1 (Tsuchida et al. 1994); T4, anti-Lim1/2 (Tsuchida et al. 1994); 4G1, anti-Msx1/2 (Riddle et al. 1995). A poptotic cell death was detected in cryostat-sectioned embryonic tissue by fluorescein-dUTP Iabeling of DNA strand breaks with the In Situ Cell Death Detection kit (Boehringer Mannheim).

\section{RT-PCR}

RT-PCR was performed as described (Tanabe et al. 1995). The primers for amplification of chick LH2A were: CLH2A3, 5'TGCAACAAGATGCTGACCACC-3' and CLH2A4, 5'-TTGACGTAGGAGGTTCCGTCTG-3'; for amplification of chick LH2B: GT52, 5'-GAGTCCCTTTTGCAAGGAGAATAC-3' and GT53, 5'-CGCTTTATCGACACCCCCATTCTC-3'; for amplification of mouse LH2A: LH2A12, 5'-TCAACCTGGAGTCGGAACTCAC-3' and LH2A4, 5'-TTGTCTTTTGGCTGCTGGGG-3'.
Neural explant culture and induction assays

Explants of chick neural plate ([i] explants) were isolated and cultured as described previously (Y amada et al. 1993; Liem et al. 1995). Explants of mouse neural tube ([d+rp] explants) from the cervical (forelimb) region were dissected in dispase, and surrounding tissues were removed. The neural tube was opened at the ventral midline, and the roof plate and dorsal one-quarter of the neural tube was isolated. Mouse explants were cultured in collagen matrices in Iscove's Modified Dulbecco's Medium (GIBCO) supplemented with Mito serum extender (Collaborative Research).

M ouse GDF7, human BM P7, and mouse BM P6 were obtained by transfection of COS-7 cells (Basler et al. 1993). To prepare a Myc-tagged GDF7 expression construct, the GDF7 carboxyterminal mature peptide coding region was first amplified by PCR with the primers: 5'-CGGAATTCGATATCCGAGGAGGACCTGAGCCGCTGCAGTCGCAAGTC-3' and 5'-AGCACTAGTATCCTACCTGCAGCCGCAGGCCT-3'. This fragment was digested with EcoRV and Spel (underlined sites) and ligated to a Asp718-EcoRV fragment encoding the aminoterminal propeptide region of DSL1 (Basler et al. 1993) to recreate the myc epitope at the junction between DSL1 and GDF7. A similar construct that expresses a fusion of the GDF7 mature peptide with the propeptide region of BM P4 was also prepared. Both fusions were cloned into the expression vector pMT21 and used to transfect COS-7 cells. The resulting supernatants containing DSL1-GDF7 or BM P4-GDF7 had qual itatively identical activities in all assays. $\mathrm{N}$ oggin was provided by Richard $\mathrm{Harland}$ (University of California, Berkeley) and Follistatin by the $\mathrm{Na}$ tional Hormone and Pituitary Program.

\section{Acknowledgments}

We thank Se-jin Lee for providing mouse and human GDF7 sequences in advance of publication and for hel pful discussions, A. Dudley, M. Solloway, and E. Robertson for Bmp mutants and CDNAs, J. Johnson for mATH1 reagents and information, G. Tremml for LH2 antisera, P. M ombaerts for ES cells and advice, D. Kingsley for communication of unpublished data, L. Carlsson and $\mathrm{H}$. Okamoto for mouse LH2B CDNA, J.C. Izpisua-Belmonte for chick LH2A cDN A, Q. Ma and D. Anderson for Ngn-1 cDNA, K. Lyons for Bmp cDNAs, and R. Harland and J. De Jesus-Escobar for Noggin. We are grateful to B. Han for expert hel $\mathrm{p}$ in cell culture, S. Brenner-M orton for advice on immunocytochemistry, R. Alcaraz for histology, and S. Kaplan, C. Lee, and M. Schiff for technical assistance. We thank R. Axel, J. Briscoe, J. Dodd, A. Hemmati-Brivanlou, K. Liem, N. Shah, C. Stern, A. Streit, and L. Vosshall for discussion and comments on this manuscript. K.J.L. was an HHMI Fellow of the Life Sciences Research Institute and T.M.J. is an Investigator of HHMI. The sequence of chick GDF6/7 has been deposited in GenBank under accession no. AF089086.

The publication costs of this article were defrayed in part by payment of page charges. This article must therefore be hereby marked 'advertisement' in accordance with 18 USC section 1734 solely to indicate this fact.

\section{References}

Akazawa, C., M. Ishibashi, C. Shimizu, S. Nakanishi, and R. Kageyama. 1995. A mammalian helix-loop-helix factor structurally related to the product of the Drosophila proneural gene atonal is a positive transcriptional regulator expressed in the developing nervous system. J. Biol. Chem. 270: 8730-8738. 
Altman, J. and S.A. Bayer. 1984. The development of the rat spinal cord. Adv. Anat. Embryol. Cell Biol. 85: 1-164.

Aono, A., M. Hazama, K. N otoya, S. Taketomi, H. Yamasaki, R. Tsukuda, S. Sasaki, and Y. Fujisawa. 1995. Potent ectopic bone-inducing activity of bone morphogenetic protein-4/7 heterodimer. Biochem. Biophys. Res. Commun. 210: 670677.

Arkell, R. and R.S.P. Beddington. 1997. BM P7 influences pattern and growth of the developing hindbrain of mouse embryos. Development 124: 1-12.

Basler, K., T. Edlund, T.M. Jessell, and T. Yamada. 1993. Control of cell pattern in the neural tube: Regulation of cell differentiation by dorsal in-1, a novel TGF beta family member. Cell 73: 687-702.

Ben-Arie, N., A.E. McCall, S. Berkman, G. Eichele, H.J. Bellen, and H.Y. Zoghbi. 1996. Evolutionary conservation of sequence and expression of the bHLH protein A tonal suggests a conserved role in neurogenesis. Hum. Mol. Genet. 5: 12071216.

Chen, H., Y. Lun, D. Ovchinnikov, H. Kokubo, K.C. Oberg, C.V. Pepicelli, L. Gan, B. Lee, and R.L. Johnson. 1998. Limb and kidney defects in Lmxlb mutant mice suggest an involvement of LMX1B in human nail patella syndrome. Nature Genet. 19: 51-55.

Chiang, C., Y. Litingtung, E. Lee, K.E. Young, J.L. Corden, H. Westphal, and P.A. Beachy. 1996. Cyclopia and defective axial patterning in mice lacking Sonic hedgehog gene function. Nature 383: 407-413.

Crossley, P.H., S. Martinez, and G.R. Martin. 1996. Midbrain development induced by FGF8 in the chick embryo. Nature 380: 66-68.

Dickinson, M.E., M.A. Selleck, A.P. McM ahon, and F.M. Bronner. 1995. Dorsalization of the neural tube by the non-neural ectoderm. Development 121: 2099-2106.

Dudley, A.T. and E.J. Robertson. 1997. Overlapping expression domains of bone morphogenetic protein family members potentially account for limited tissue defects in BM P7 deficient embryos. Dev. Dyn. 208: 349-362.

Dudley, A.T., K.M. Lyons, and E.J. Robertson. 1995. A requirement for bone morphogenetic protein-7 during development of the mammalian kidney and eye. Genes \& Dev. 9: 27952807.

Ericson, J., S. M orton, A. Kawakami, H. Roelink, and T.M. Jessell. 1996. Two critical periods of Sonic Hedgehog signaling required for the specification of motor neuron identity. Cell 87: 661-673.

Ericson, J., P. Rashbass, A. Schedl, S. Brenner-Morton, A. Kawakami, V. van Heyningen, T.M. Jessell, and J. Briscoe. 1997. Pax6 controls progenitor cell identity and neuronal fate in response to graded Shh signaling. Cell 90: 169-180.

Furuta, Y., D.W. Piston, and B.L.M. Hogan. 1997. Bone morphogenetic proteins (BM Ps) as regulators of dorsal forebrain development. Development 124: 2203-2212.

Helms, A.W. and J.E. Johnson. 1998. Progenitors of dorsal commissural interneurons are defined by mATH1 expression. Development 125: 919-928.

Hogan, B.L. 1996. Bone morphogenetic proteins in development. Curr. Opin. Gen. Dev. 6: 432-438.

Holley, S.A., J.L. N eul, L. Attisano, J.L. Wrana, Y. Sasai, M.B. O'Connor, E.M. De Robertis, and E.L. Ferguson. 1996. The Xenopus dorsalizing factor noggin ventralizes Drosophila embryos by preventing DPP from activating its receptor. Cell 86: 607-617.

Hooper, M., K. Hardy, A. Handyside, S. Hunter, and M. Monk. 1987. HPRT-deficient (Lesch-N yhan) mouse embryos derived from germline colonization by cultured cells. Nature
326: 292-295.

Ikeya, M., S.M.K. Lee, J.E. Johnson, A.P. McMahon, and S. Takada. 1997. Wnt signalling required for expansion of neural crest and CN S progenitors. Nature 389: 966-970.

Jones, C.M., K.M. Lyons, and B.L. Hogan. 1991. Involvement of bone morphogenetic protein-4 (BM P-4) and Vgr-1 in morphogenesis and neurogenesis in the mouse. Development 111: 531-542.

King, J.A., P.C. Marker, K.J. Seung, and D.M. Kingsley. 1994. BM P5 and the molecular, skel etal and soft-tissue al terations in short ear mice. Dev. Biol. 166: 112-122.

Kingsley, D. 1994. The TGF $\beta$ superfamily: N ew members, new receptors, and new genetic tests of function in different organisms. Genes \& Dev. 8: 133-146.

Leber, S.M . and J.R. Sanes. 1995. M igratory paths of neurons and glia in the embryonic chick spinal cord. J. Neurosci. 15: $1236-1248$.

Lee, S.M.K., P.S. Danielian, B. Fritzsch, and A.P. McMahon. 1997. Evidence that FGF8 signal ing from the midbrain-hindbrain junction regulates growth and polarity in the developing midbrain. Development 124: 959-969.

Liem, K.F., G. Tremml, H. Roelink, and T.M. Jessell. 1995. Dorsal differentiation of neural plate cells induced by BM P-mediated signals from epidermal ectoderm. Cell 82: 969-979.

Liem, K.F., G. Tremml, and T.M. Jessell. 1997. A role for the roof plate and its resident TGF $\beta$-related proteins in neuronal patterning in the dorsal spinal cord. Cell 91: 127-138.

Lumsden, A. and R. Krumlauf. 1996. Patterning the vertebrate neuraxis. Science 274: 1109-1115.

Luo, G., C. Hofmann, A.L.J. Bronckers, M. Sohocki, A. Bradley, and G. Karsenty. 1995. BM P-7 is an inducer of nephrogenesis, and is also required for eye development and skel etal patterning. Genes \& Dev. 9: 2808-2820.

Lyons, K.M., R.W. Pelton, and B.L.M. Hogan. 1989. Patterns of expression of murine Vgr-1 and BM P-2a RN A suggest that transforming growth factor- $\beta$-like genes coordinately regulate aspects of embryonic development. Genes \& Dev. 3: $1657-1668$.

Lyons, K.M., B.L. Hogan, and E.J. Robertson. 1995. Colocalization of BM P 7 and BM P 2 RN As suggests that these factors cooperatively mediate tissue interactions during murine devel opment. Mech. Dev. 50: 71-83.

Ma, Q., C. Kintner, and D.J. Anderson. 1996. Identification of neurogenin, a vertebrate neuronal determination gene. Cell 87: 43-52.

MacKenzie, A., M.W.J. Ferguson, and P.T. Sharpe. 1991. Hox-7 expression during murine craniofacial development. Development 113: 601-611.

Marti, E., D.A. Bumcrot, R. Takada, and A.P. M cM ahon. 1995. Requirement of 19K form of Sonic hedgehog for induction of distinct ventral cell types. Nature 375: 322-325.

M cM ahon, A.P. and A. Bradley. 1990. The Wnt-1 (int-1) protooncogene is required for development of a large region of the mouse brain. Cell 62: 1073-1085.

McMahon, J.A., S. Takada, L.B. Zimmerman, C.M. Fan, R.M. Harland, and A.P. MCM ahon. 1998. N oggin-mediated antagonism of BMP signaling is required for growth and patterning of the neural tube and somite. Genes \& Dev. 12: 1438-1452.

Meyers, E.N., M. Lewandoski, and G.R. Martin. 1998. An Fgf8 mutant allelic series generated by $\mathrm{Cre}$ - and Flp-mediated recombination. Nature Genet. 18: 136-141.

Monaghan, A.P., D.R. Davidson, C. Sime, E. Graham, R. Baldock, S.S. Bhattacharya, and R.E. Hill. 1991. The Msh-like homeobox genes define domains in the developing vertebrate eye. Development 112: 1053-1061. 
Moury, J.D. and A.G. Jacobson. 1989. N eural fold formation at newly created boundaries between neural plate and epidermis in the axolotl. Dev. Biol. 133: 44-57.

Nakamura, T., K. Takio, Y. Eto, H. Shibai, K. Titani, and H. Sugino. 1990. Activin-binding protein from rat ovary is follistatin. Science 247: 836-838.

N ornes, H.O. and G.D. Das. 1974. Temporal pattern of neurogenesis in spinal cord of rat. I. An autoradiographic studytime and sites of origin and migration and settling patterns of neuroblasts. Brain Res. 73: 121-138.

Parr, B.A., M.J. Shea, and A.P. McMahon. 1993. Mouse Wnt genes exhibit discrete domains of expression in its early embryonic CNS and limb buds. Development 119: 247-261.

Pfaff, S.L., M. M endel sohn, C.L. Stewart, T. Edlund, and T.M. Jessell. 1996. Requirement for LIM homeobox gene IsI 1 in motor neuron generation reveals a motor neuron-dependent step in interneuron differentiation. Cell 84: 1-20.

Riddle, R.D., M. Ensini, C. N elson, T. Tsuchida, T.M. Jessell, and C. Tabin. 1995. Induction of the LIM homeobox gene Lmxl by WN T 7a establishes dorsoventral pattern in the vertebrate limb. Cell 83: 631-640.

Rissi, M., J. Wittbrodt, E. Delot, M. N aegeli, and F.M. Rosa. 1995. Zebrafish Radar: A new member of the TGF-beta superfamily defines dorsal regions of the neural plate and the embryonic retina. Mech. Dev. 49: 223-234.

Roelink, H., J.A. Porter, C. Chiang, Y. Tanabe, D.T. Chang, P.A. Beachy, and T.M. Jessell. 1995. Floor plate and motor neuron induction by different concentrations of the amino-terminal cleavage product of sonic hedgehog autoproteolysis. Cell 81: 445-455.

Schaeren-Wiemers, N . and A. Gerfin-M oser. 1993. A single protocol to detect transcripts of various types and expression levels in neural tissue and cultured cells: In situ hybridization using digoxigenin-labelled cRN A probes. Histochemistry 100: 431-440.

Shah, N.M., A.K. Groves, and D.J. Anderson. 1996. Alternative neural crest cell fates are instructively promoted by TGF $\beta$ superfamily members. Cell 85: 331-343.

Shimamura, K., D.J. Hartigan, S. Martinez, L. Puelles, and J.L. Rubenstein. 1995. Longitudinal organization of the anterior neural plate and neural tube. Development 121: 3923-3933.

Storm, E.E., T.V. Huynh, N.G. Copeland, N.A. Jenkins, D.M. Kingsley, and S.-J. Lee. 1994. Limb alterations in brachypodism mice due to mutations in a new member of the TGF $\beta$ superfamily. Nature 368: 639-643.

Suzuki, A., E. Kaneko, J. M aeda, and N. U eno. 1997. M esoderm induction by BM P-4 and -7 heterodimers. Biochem. Biophys. Res. Commun. 232: 153-156.

Tanabe, Y. and T.M. Jessell. 1996. Diversity and pattern in the developing spinal cord. Science 274: 1115-1123.

Tanabe, Y., H. Roelink, and T. Jessell. 1995. Induction of motor neurons by Sonic hedgehog is independent of floor plate differentiation. Curr. Biol. 5: 651-658.

Thomas, K.R. and M.R. Capecchi. 1990. Targeted disruption of the murine int-1 proto-oncogene resulting in severe abnormalities in midbrain and cerebellar development. Nature 346: 847-850.

Tsuchida, T., M. Ensini, S.B. M orton, M. Bal dassare, T. Edlund, T.M. Jessell, and S.L. Pfaff. 1994. Topographic organization of embryonic motor neurons defined by expression of LIM homeobox genes. Cell 79: 957-970.

Winnier, G., M. Blessing, P.A. Labosky, and B.L. Hogan. 1995. Bone morphogenetic protein-4 is required for mesoderm formation and patterning in the mouse. Genes \& Dev. 9: 21052116.

Xu, Y., M. Baldassare, P. Fisher, G. Rathbun, E.M. Oltz, G.D.
Yancopoulos, T.M. Jessell, and F.W. Alt. 1993. LH-2: A LIM / homeodomain gene expressed in developing lymphocytes and neural cells. Proc. Natl. Acad. Sci. 90: 227-231.

Yamada, T., S.L. Pfaff, T. Edlund, and T.M. Jessell. 1993. Control of cell pattern in the neural tube: Motor neuron induction by diffusible factors from notochord and floor plate. Cell 73: 673-686.

Yamashita, H., P. ten Dijke, D. Huylebroeck, T.K. Sampath, M. Andries, J.C. Smith, C.H. Heldin, and K. Miyazono. 1995. Osteogenic protein-1 binds to activin type II receptors and induces certain activin-like effects. J. Cell Biol. 130: 217226.

Ye, W., K. Shimamura, J.L.R. Rubenstein, M.A. Hynes, and A. Rosenthal. 1998. FGF and Shh signals control dopaminergic and serotonergic cell fate in the anterior neural plate. Cell 93: 755-766.

Zhang, H. and A. Bradley. 1996. Mice deficient for BMP2 are nonviable and have defects in amnion/chorion and cardiac development. Development 122: 2977-2986.

Zimmerman, L.B., J.M. De Jesus-Escobar, and R.M. Harland. 1996. The Spemann organizer signal noggin binds and inactivates bone morphogenetic protein 4. Cell 86: 599-606. 


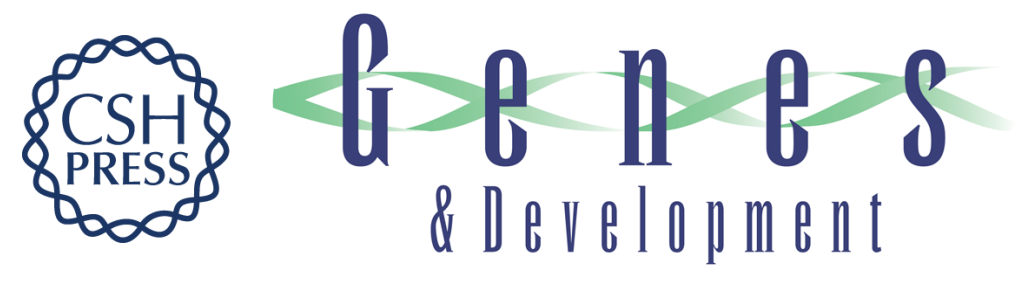

\section{Neuronal patterning by BMPs: a requirement for GDF7 in the generation of a discrete class of commissural interneurons in the mouse spinal cord}

Kevin J. Lee, Monica Mendelsohn and Thomas M. Jessell

Genes Dev. 1998, 12:

Access the most recent version at doi:10.1101/gad.12.21.3394

$\begin{array}{ll}\text { References } & \begin{array}{l}\text { This article cites } 62 \text { articles, } 24 \text { of which can be accessed free at: } \\ \text { http://genesdev.cshlp.org/content/12/21/3394.full.html\#ref-list-1 }\end{array}\end{array}$

License

Email Alerting Receive free email alerts when new articles cite this article - sign up in the box at the top Service right corner of the article or click here.

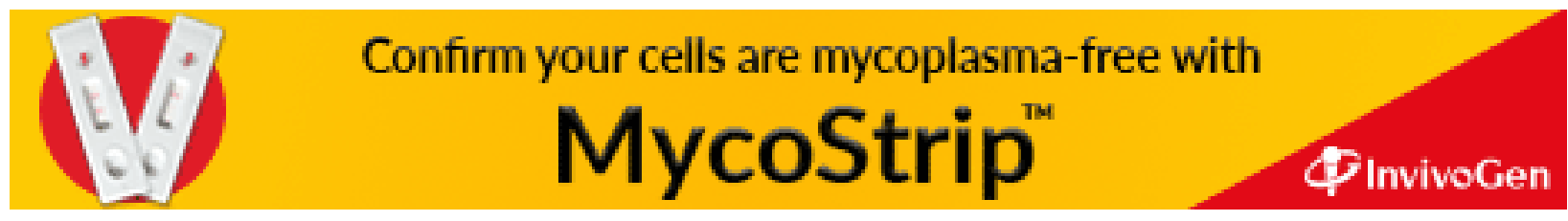

